U.S. Department of the Interior

U.S. Geological Survey

Prepared in cooperation with the

Environmental Directorate

Naval Weapons Station Yorktown

\title{
Ground-Water Flow in the Shallow Aquifer System at the Naval Weapons Station Yorktown, Virginia
}

Water-Resources Investigations Report 00-4077

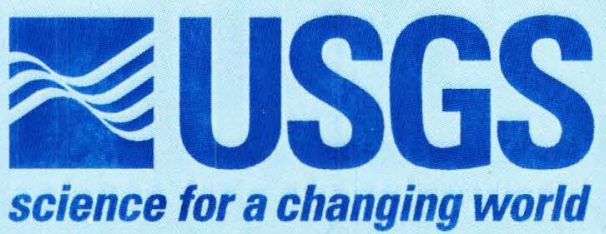


U.S. Department of the Interior

U.S. Geological Survey

\section{Ground-Water Flow in the Shallow Aquifer System at the Naval Weapons Station Yorktown, Virginia}

By Barry S. Smith

Water-Resources Investigations Report 00-4077

Prepared in cooperation with the

Environmental Directorate

Naval Weapons Station Yorktown

Richmond, Virginia

2001 


\section{U.S. DEPARTMENT OF THE INTERIOR \\ BRUCE BABBITT, Secretary}

U.S. GEOLOGICAL SURVEY

Charles G. Groat, Director

The use of trade or product names in this report is for identification purposes only and does not constitute endorsement by the U.S. Geological Survey.

For additional information write to:

District Chief

U.S. Geological Survey

1730 East Parham Road

Richmond, VA 23228
Copies of this report can be purchased from:

U.S. Geological Survey Branch of Information Services Box 25286, Federal Center Denver, CO 80225-0286 


\section{CONTENTS}

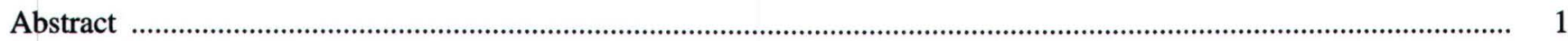

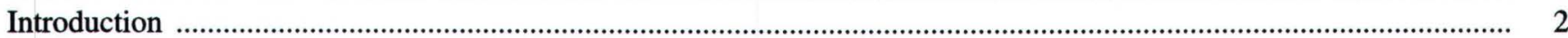

Purpose and Scope

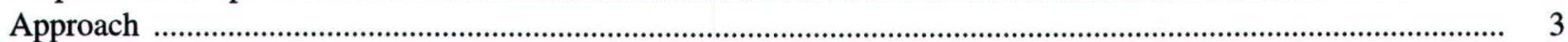

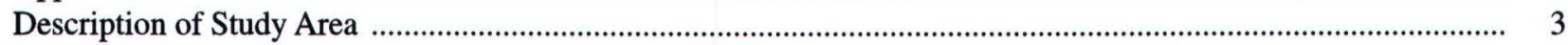

Previous Studies

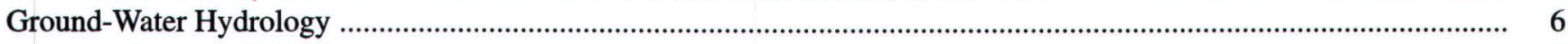

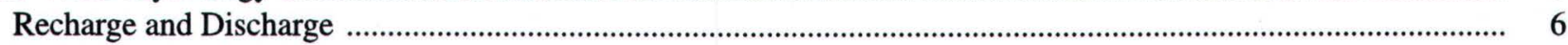

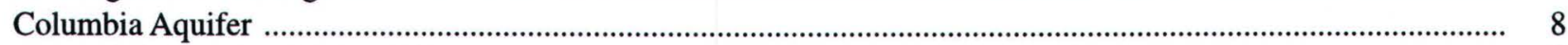

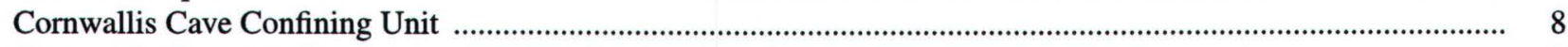

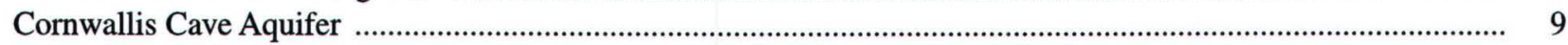

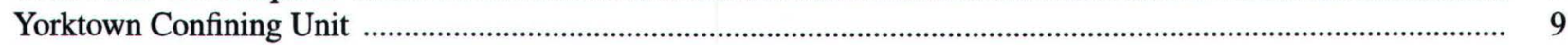

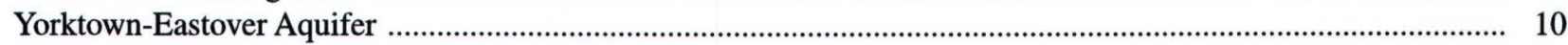

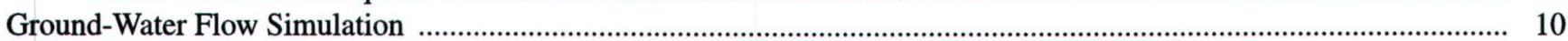

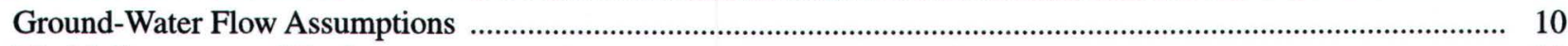

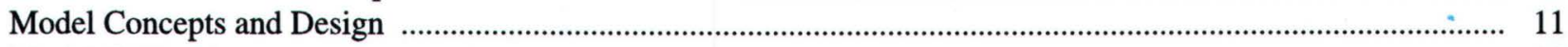

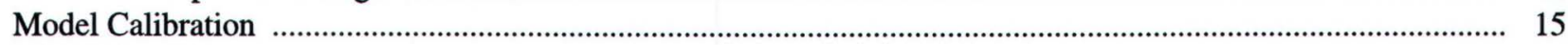

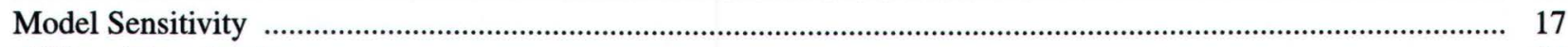

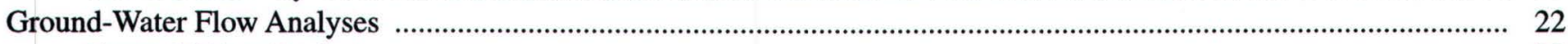

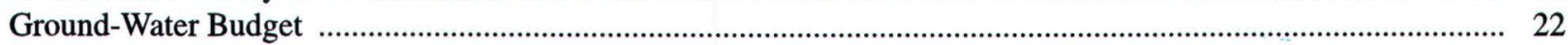

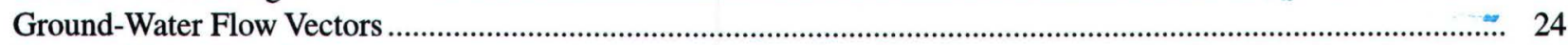

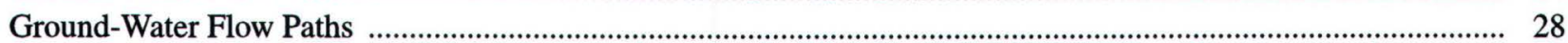

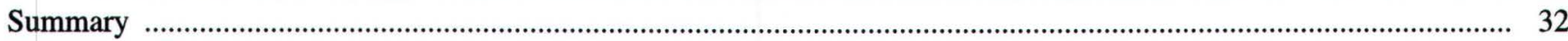

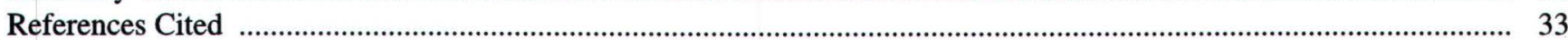

\section{FIGURES}

1-2. Maps showing:

1. Location of the Naval Weapons Station Yorktown, Virginia (study area) .................................................... 4

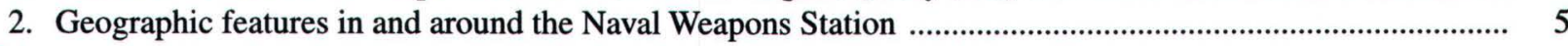

3. Diagrammatic section showing geohydrologic units and general ground-water flow

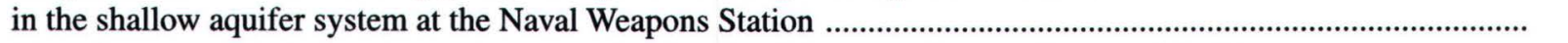

4. Map showing grid, drain cells, and constant-head cells of the ground-water flow model of the

Naval Weapons Station area

5. Diagram showing geohydrologic units and layers of the ground-water flow model ..............................................13

6-7. Maps showing:

6. Extent of the Columbia and Cornwallis Cave aquifers in layer 1 of the ground-water flow model

7. Extent of the Yorktown confining unit and the Yorktown-Eastover aquifer in layer 2 of the ground-water flow model

8. Graph showing measured and simulated water levels of the calibrated ground-water flow model

11. Map showing:

9. Measured and simulated water levels in layer 1 of the ground-water flow model

10. Measured and simulated water levels in layer 2 of the ground-water flow model

11. Measured and simulated water levels in layer 3 of the ground-water flow model

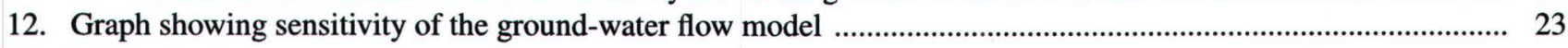

13-16. Maps showing

13. Vectors simulated for layer 1 of the ground-water flow model

14. Vectors simulated for layer 2 of the ground-water flow model 
15. Vectors simulated for layer 3 of the ground-water flow model

16. Ground-water flow paths simulated from the drainage divide near the southern perimeter of the Naval Weapons Station

17. Ground-water flow paths simulated from sites 11 and 17 of the Naval Weapons Station

18. Simulated ground-water flow paths from site 17 of the Naval Weapons Station

\section{TABLES}

1. Horizontal hydraulic conductivity of the shallow aquifer system in and around the Naval Weapons Station

2. Vertical hydraulic conductivity of the shallow aquifer system in and around the Naval Weapons Station

3. Ground-water flow budget of the Naval Weapons Station-area model

\section{CONVERSION FACTORS, ABBREVIATIONS, VERTICAL DATUM, AND HYDRAULIC CONDUCTIVITY}

\begin{tabular}{|c|c|c|}
\hline Multiply & By & To obtain \\
\hline \multicolumn{3}{|c|}{ Length } \\
\hline inch (in.) & 2.54 & centimeter \\
\hline foot (ft) & 0.3048 & meter \\
\hline mile (mi) & 1.609 & kilometer \\
\hline \multicolumn{3}{|c|}{ Area } \\
\hline square foot $\left(\mathrm{ft}^{2}\right)$ & 0.09290 & square meter \\
\hline square mile $\left(\mathrm{mi}^{2}\right)$ & 2.590 & square kilometer \\
\hline \multicolumn{3}{|c|}{ Volume } \\
\hline cubic foot $\left(\mathrm{ft}^{3}\right)$ & 0.02832 & cubic meter \\
\hline \multicolumn{3}{|c|}{ Velocity } \\
\hline foot per day $(\mathrm{ft} / \mathrm{d})$ & 0.3048 & meter per day \\
\hline foot per year (ft/yr) & 0.3048 & meter per year \\
\hline \multicolumn{3}{|c|}{ Volumetric flow rate } \\
\hline cubic foot per day $\left(\mathrm{ft}^{3} / \mathrm{d}\right)$ & 0.02832 & cubic meter per day \\
\hline \multicolumn{3}{|c|}{ Recharge rate } \\
\hline inch per year (in/yr) & 25.4 & millimeter per year \\
\hline \multicolumn{3}{|c|}{ Hydraulic conductivity } \\
\hline foot per day $(\mathrm{ft} / \mathrm{d})$ & 0.3048 & meter per day \\
\hline
\end{tabular}

Temperature in degrees Celsius $(\mathrm{C})$ may be converted to degrees Fahrenheit $(\mathrm{F})$ as follows: ${ }^{\circ} \mathrm{F}=\left(1.8 \times{ }^{\circ} \mathrm{C}\right)+32$

Vertical datum: In this report, "sea level" refers to the National Geodetic Vertical Datum of 1929 (NGVD of 1929)-a geodetic datum derived from a general adjustment of the first-order level nets of both the United States and Canada, formerly called Sea Level Datum of 1929.

Altitude, as used in this report, refers to distance above or below sea level.

Hydraulic conductivity: Hydraulic conductivity is reported in foot per day (ft/d), a mathematical reduction of the unit square foot per day per foot of thickness $\left[\left(\mathrm{ft}^{2} / \mathrm{d}\right) / \mathrm{ft}\right]$. 


\title{
Ground-Water Flow in the Shallow Aquifer System at the Naval Weapons Station Yorktown, Virginia
}

\author{
By Barry S. Smith
}

\section{ABSTRACT}

The Environmental Directorate of the Naval Weapons Station Yorktown, Virginia, is concerned about possible contamination of ground water at the Station. Ground water at the Station flows through a shallow system of layered aquifers and leaky confining units. The units of the shallow aquifer system are the Columbia aquifer, the Cornwallis Cave confining unit, the Cornwallis Cave aquifer, the Yorktown confining unit, and the Yorktown-Eastover aquifer. The Eastover-Calvert confining unit separates the shallow aquifer system from deeper confined aquifers beneath the Station.

A three-dimensional, finite-difference, ground-water flow model was used to simulate steady-state ground-water flow of the shallow aquifer system in and around the Station. The model simulated ground-water flow from the peninsular drainage divide that runs across the Lackey Plain near the southern end of the Station north to King Creek and the York River and south to Skiffes Creek and the James River. The model was calibrated by minimizing the root mean square error between 47 measured and corresponding simulated water levels. The calibrated model was used to determine the ground-water budget and general directions of ground-water flow. A particle-tracking routine was used with the calibrated model to estimate groundwater flow paths, flow rates, and traveltimes from selected sites at the Station.

Simulated ground-water flow velocities of the Station-area model were small beneath the interstream areas of the Lackey Plain and Croaker Flat, but increased outward toward the streams and rivers where the hydraulic gradients are larger. If contaminants from the land surface entered the water table at or near the interstream areas of the Station, where hydraulic gradients are smaller, they would migrate more slowly than if they entered closer to the streams or the shores of the rivers where gradients commonly are larger.

The ground-water flow simulations indicate that some ground water leaks downward from the water table to the Yorktown confining unit and, where the confining unit is absent, to the Yorktown-Eastover aquifer. The velocities of advective-driven contaminants would decrease considerably when entering the Yorktown confining unit because the hydraulic conductivity of the confining unit is small compared to that of the aquifers.

Any contaminants that moved with advective ground-water flow near the groundwater divide of the Lackey Plain would move relatively slowly because the hydraulic gradients are small there. The direction in which the contaminants would move, however, would be determined by precisely where the contaminants entered the water table. The model was not designed to accurately simulate ground-water flow paths through local karst features.

Beneath Croaker Flat, ground water flows downward through the Columbia aquifer and the Yorktown confining unit into the YorktownEastover aquifer. Analyses of the movement of simulated particles from two adjacent sites at Croaker Flat indicated that ground-water flow paths were similar at first but diverged and discharged to different tributaries of Indian Field Creek or to the York River. These simulations indicate that complex and possibly divergent flow paths and traveltimes are possible at the Station. Although the Station-area model is not detailed 
enough to simulate ground-water flow at the scales commonly used to track and remediate contaminants at specific sites, general concepts about possible contaminant migration at the Station can be inferred from the simulations.

\section{INTRODUCTION}

The Environmental Directorate of the Naval Weapons Station Yorktown, Virginia, is concerned about contamination of ground water at the Station. Hazardous-waste sites have been identified and investigated at the Station since 1984 (C.C. Johnson and Associates, Inc. \& CH2MHill, 1984). The Station was placed on the National Priorities (Superfund) List in 1992. In 1994, the U.S. Navy, the U.S.

Environmental Protection Agency, and the Virginia Department of Environmental Quality signed a Federal Facilities Agreement, which allowed federal and state agencies as well as local citizens to participate in a Restoration Advisory Board (U.S. Environmental Protection Agency Region III, 1994). The Board aids in decisions about cleanup of contaminated sites at the Station. A Site Management Plan for the Station was completed in fiscal year 1994, and restoration of individual sites will continue through the year 2000 .

The primary mission of the Station is to provide ordnance, technical support, and related services to the armed forces of the United States (U.S. Department of the Navy, 1995, p. 5-362). The Station was originally commissioned by Presidential Proclamation in 1918 as the U.S. Mine Depot (Naval Weapons Station, 1993, p. 12). The mission of the Depot was to reclaim, store, and issue mines, depth charges, and related materials for the Atlantic Fleet. In 1927, reclaiming and loading of trinitrotoluene (TNT) began at the Depot. The facilities, roads, rails, and piers of the Depot occupied a small part of the original tract, which was mostly farmland and waterways. The open farmlands were generally allowed to revert to forest after the government claimed the land.

More facilities and roads were added as needed. During World War II, high explosives were designed, filled, serviced, and stored at the Depot. In addition, rocket projectiles, advanced underwater ordnance, bombs, antisubmarine devices, and warheads were produced. Torpedo overhaul facilities were added. During the Korean War in the early 1950 's, bombs were produced at the Depot (Naval Weapons Station, 1993, p. 14).
The Depot was redesignated the Naval Weapons Station in 1958 and continued to provide naval weapons support including the handling of nuclear munitions for bombs and missiles, as well as providing the traditional weapons support for the U.S. Navy (Federation of American Scientists, 1997). Bombs were produced at the Station during the Vietnam War and missiles were tested during the Gulf War (Naval Weapons Station, 1993, p. 14). The last major ordnance plant at the Station ceased production in 1994; however, the Station continues to provide maintenance, storage, and distribution of ordnance to the Atlantic Fleet.

The U.S. Geological Survey (USGS), in cooperation with the Environmental Directorate of the Naval Weapons Station, began an investigation of the shallow aquifer system at the Station in 1995 and published a report on the geohydrology of the shallow aquifers at the Station in 1997 (Brockman and others, 1997). The USGS defined the geohydrologic framework of the shallow aquifer system in and around the Station and determined hydraulic properties of the geohydrologic units by drilling test holes, taking soil and Shelby tube samples, and installing piezometers and wells. The report suggested that a more rigorous analysis of ground-water flow directions and rates could be accomplished by the design and use of a numerical ground-water flow model (Brockman and others, 1997, p. 44). In 1998, the USGS, in cooperation with the Environmental Directorate of the Station, began an analysis of ground-water flow in the shallow aquifer system in and around the Station by use of a numerical ground-water flow model. The objectives of this study were to (1) calculate the ground-water budget of the shallow aquifer system, (2) determine the general directions of ground-water flow in the shallow aquifer system, and (3) estimate the flow paths and traveltimes for ground-water flow at selected sites of the Station.

\section{Purpose and Scope}

This report presents an analysis of ground-water flow for the shallow aquifer system in and around the Station. The report describes the simulation of advective ground-water flow in and around the Station by a three-dimensional, finite-difference, ground-water flow model. Advective flow is the bulk or mass movement of ground water without regard to the 
processes of solute transport such as dispersion or diffusion.

Analyses of ground-water flow based on the results from the computer simulations described and depicted in this report are intended to provide technical information for the environmental restoration program of the Station and will aid in the prudent management of the ground-water resources of the shallow aquifer system in and around the Station.

\section{Approach}

Information from previous studies was used to design and calibrate a three-dimensional, finitedifference, ground-water flow model representing the shallow aquifer system in and around the Station. The steady-state, ground-water flow model was calibrated by minimizing the RMSE (root mean square error) between measured and simulated water levels. Water levels measured in 47 wells at the Station on or about February 3, 1997, were used for the calibration (Brockman and others, 1997, table 2). The calibrated model was then used to meet the objectives stated above.

Visual MODFLOW, version 2.8 (c) 1995-1999, the Waterloo Hydrogeologic, Inc. extension of the USGS three-dimensional, finite-difference, groundwater flow model MODFLOW (Harbaugh and McDonald, 1996) was used to simulate and depict ground-water flow for this study. Visual MODFLOW also includes the USGS particle-tracking program MODPATH (Pollock, 1994), a vector plotting postprocessor, and the USGS volumetric budget calculator ZONEBUDGET (Harbaugh, 1990), as well as a statistical calibration program and other graphic postprocessors that were used in this study.

\section{Description of Study Area}

The Naval Weapons Station is on 10,624 acres of woodlands and wetlands on the south bank of the York River estuary near Yorktown, Va. (fig. 1). The Station is entirely within the Coastal Plain Physiographic Province of Virginia. The Camp Peary scarp, a bluff near the York River formed by shoreline erosion when sea levels were higher, separates the Station into a higher and a lower terrace (Johnson, 1972, p. 10). The Lackey Plain, the higher terrace, has altitudes higher than $90 \mathrm{ft}$ above sea level in a few places; Croaker Flat, the lower terrace, has altitudes generally less than $45 \mathrm{ft}$ above sea level.

The Lackey Plain is deeply dissected by streams at the Station. Felgates Creek and its tributaries drain most of the Station northward to the York River (fig. 2). Felgates Creek is impounded at the Camp Peary scarp. From the impoundment, Felgates Creek follows the scarp westward where it joins two tributaries and opens into a tidal bay adjacent to the York River. King Creek, a low tidal creek along the northwestern boundary of the Station drains that perimeter. Some of the headwaters of King Creek and some of its tributaries are also impounded. Skiffes Creek and its tributaries drain the southern part of the Station beyond the southern perimeter at Interstate 64 south through Skiffes Creek Reservoir to the James River. The southeastern perimeter of the Station is drained by several small streams that have headwaters near State Route 238. The northeastern part of the Station along the York River is drained by several small streams, some of which also are impounded.

\section{Previous Studies}

The analyses of ground-water flow and the numerical flow model of the shallow aquifer system presented in this report are based primarily on the geohydrologic framework and other geohydrologic information for the Station documented by Brockman and others (1997). Aquifers and confining units within the boundaries of the Station were defined and mapped in that study; hydraulic properties of aquifers and confining units, were analyzed; and ground-water flow was described in general across the Station and in detail at seven sites where well clusters were installed.

The ground-water resources of the York-James Peninsula, on which the Station is located, were described by Laczniak and Meng (1988). The geohydrology and simulation of ground-water flow for the shallow aquifer system and the deeper confined aquifers of the York-James Peninsula were documented in that report and information was presented on ground-water use, ground-water quality, and hydraulic characteristics of aquifers and confining units.

The ground-water flow system of the Coastal Plain of Virginia and a ground-water flow model of the Coastal Plain, including the shallow aquifer system and the deeper confined aquifers, were described by Harsh 


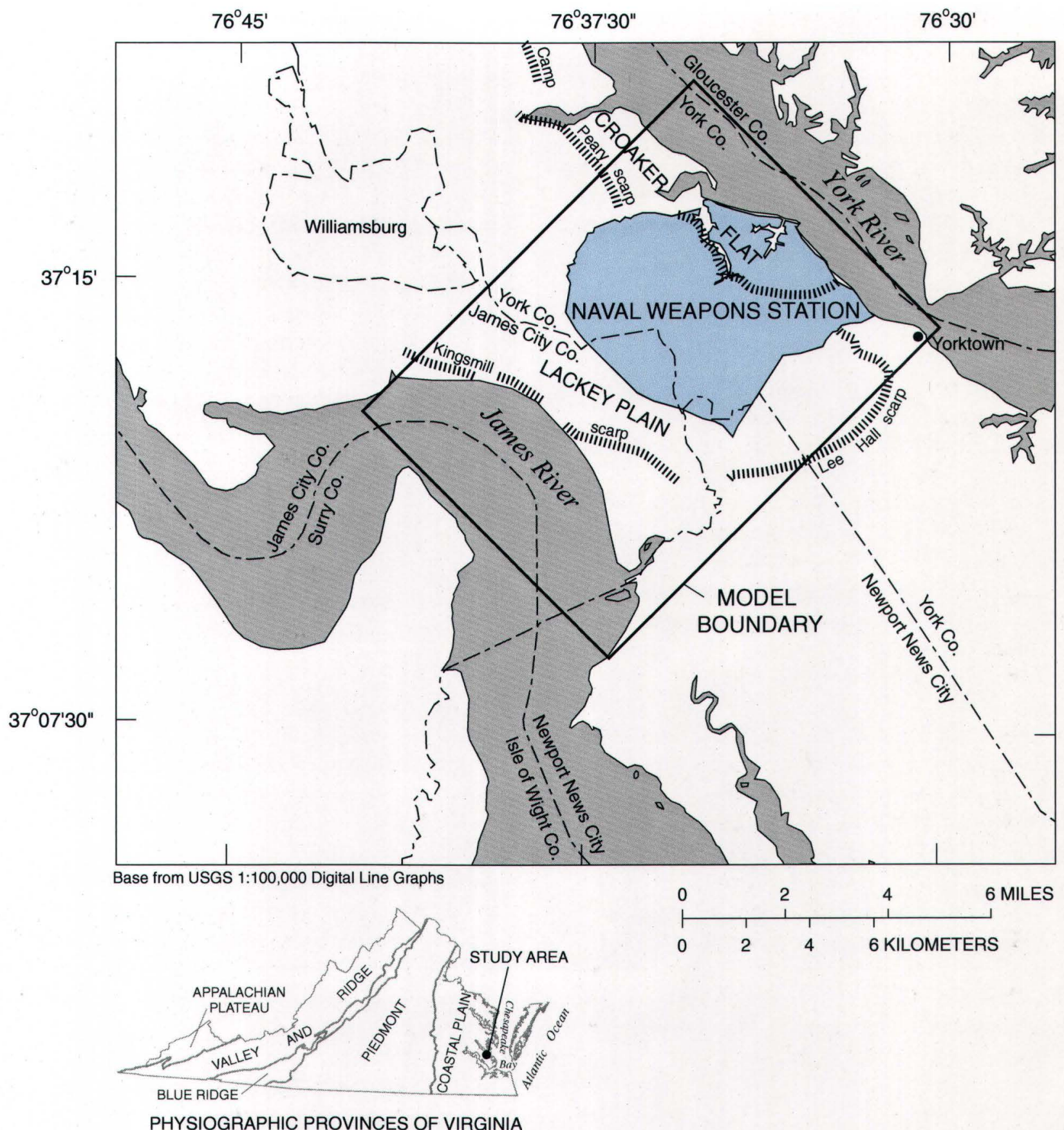

Figure 1. Location of the Naval Weapons Station Yorktown, Virginia (study area). 


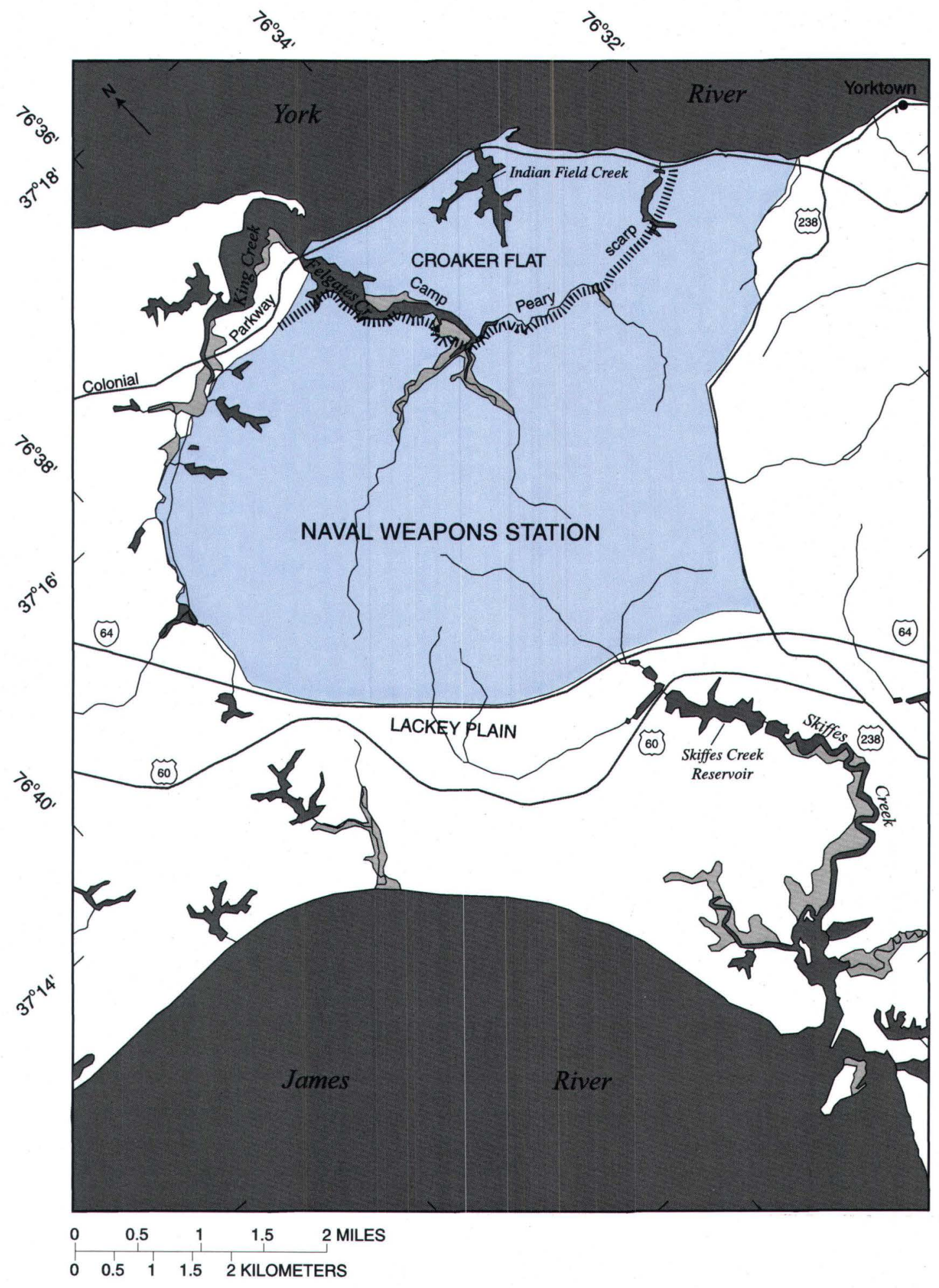

EXPLANATION

WETLANDS

Figure 2. Geographic features in and around the Naval Weapons Station Yorktown, Virginia. 
and Laczniak (1990). Hydraulic properties of aquifers and confining units were documented; geohydrologic units were described; ground-water movement and use were discussed, and the results of regional groundwater flow simulations were described and analyzed in that report.

Estimates of average annual ground-water discharge from watersheds of the Coastal Plain of Virginia were determined by Richardson (1994). These estimates, which also are used to estimate groundwater recharge, were based on separation of streamflow hydrographs of long-term gages and on a hydrogeologic area approach whereby ground-water discharges were determined based on watershed characteristics, in particular, surficial geology and soil drainage.

\section{GROUND-WATER HYDROLOGY}

The Naval Weapons Station Yorktown is located within the Coastal Plain of Virginia. Sediments beneath the Coastal Plain of Virginia have been defined as a layered sequence of aquifers and intervening confining units by the Regional Aquifer System Analysis (RASA) program of the USGS (Meng and Harsh, 1988, p. C11). Sand, gravel, and shell deposits of sufficient saturated thickness to yield significant quantities of water have been defined as aquifers. Continuous deposits of clay and silt have been defined as confining units.

Ground water at the Station flows through a shallow system of layered aquifers and leaky confining units defined by Brockman and others (1997, p. 13). The units of the shallow aquifer system are the Columbia aquifer, the Cornwallis Cave confining unit, the Cornwallis Cave aquifer, the Yorktown confining unit, and the Yorktown-Eastover aquifer. A relatively thick, continuous regional confining unit called the Eastover-Calvert confining unit separates the shallow aquifer system from deeper confined aquifers beneath the Station (fig. 3).

The Columbia, Cornwallis Cave, and YorktownEastover aquifers are separated by two relatively thin confining units beneath the Lackey Plain south of the Station (Brockman and others, 1997, p. 19 and 26). The uppermost confining unit is the Cornwallis Cave confining unit and the lower confining unit is the Yorktown confining unit. Beneath Croaker Flat north of the Camp Peary scarp, only the Columbia and
Yorktown-Eastover aquifers have been identified, and they are separated by the Yorktown confining unit (Brockman and others, 1997, p. 44).

\section{Recharge and Discharge}

Ground-water recharge is that part of precipitation that reaches the saturated surface of the water-table aquifer. Water in the shallow aquifer system flows from interstream areas beneath higher altitudes at the Station to streams, springs, and estuaries at lower altitudes where it is discharged (fig. 3). From the top of the surficial aquifer, water flows slowly downward and outward through the interconnected openings between the sediments that form the framework of the aquifer. Where water percolates to the top of the surficial aquifer faster than it can flow away, it tends to form a mound. Groundwater mounds are common in areas far from rivers, streams, marshes, and shorelines where ground water tends to discharge. Ground-water levels are lower near streams, rivers, and shorelines where hydraulic pressures are reduced by the release of water.

Annual ground-water recharge ranges from 7.5 to $12.5 \mathrm{in} / \mathrm{yr}$ and averages $10.8 \mathrm{in} / \mathrm{yr}$ in the Virginia Coastal Plain, based on the separation of streamflow hydrographs for 16 gaging stations with at least 10 years of record and assuming that surface-water and ground-water divides coincide (Richardson, 1994, p. 14). The annual ground-water discharge for any area of the Virginia Coastal Plain averages $9.9 \mathrm{in} / \mathrm{yr}$, based on a regional regression of ground-water discharge at those 16 stations and the hydrogeologic characteristics of those watersheds (in particular, surficial geology and soil drainage).

At the Station, the shallow aquifer system is recharged by precipitation that percolates through the unsaturated zone to the water table. Recharge to the York River watersheds draining the Station was estimated at $9.9 \mathrm{in} / \mathrm{yr}$ and that to the James River watersheds draining the Station was estimated at $9.7 \mathrm{in} /$ yr, assuming that surface and ground-water divides coincide (Richardson, 1994, p. 12). The apparent age of ground water at the Station, as determined by analyses of the chlorofluorocarbons, suggests that the recharge rates may be slightly less than those estimated by Richardson (D.L. Nelms, U.S. Geological Survey, written commun., 1999). 

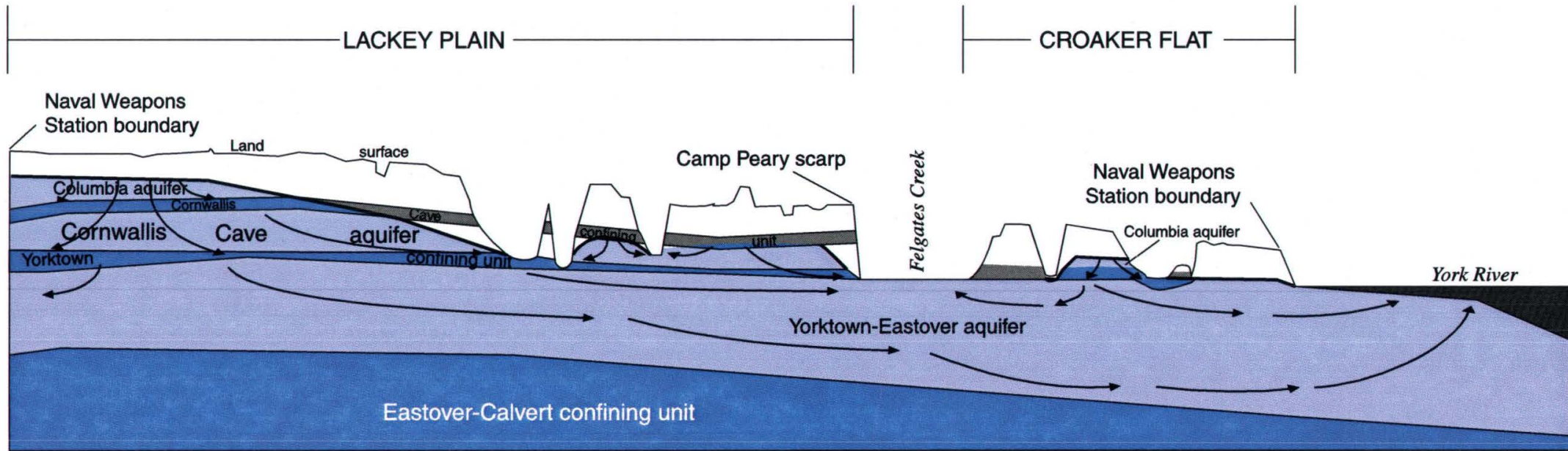

NOT TO SCALE

\section{EXPLANATION}

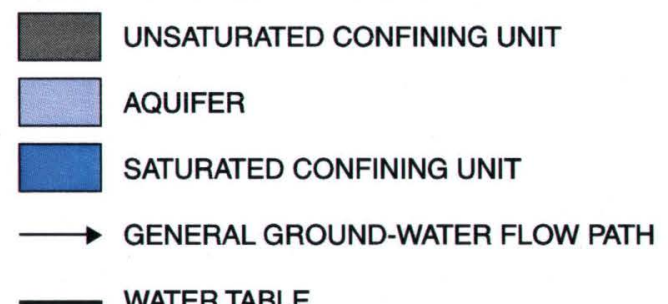

Figure 3. Geohydrologic units and general ground-water flow in the shallow aquifer system at the Naval Weapons Station Yorktown, Virginia. 


\section{Columbia Aquifer}

The Columbia aquifer consists of very fine to very coarse grained sand with or without pebbles, silty to clayey sand, or sandy clay (Brockman and others, 1997, p. 14). The Columbia is generally unconfined and discontinuous at the Station (Brockman and others, 1997, p. 16). The top and thickness of the aquifer fluctuate with the water table, and perched aquifers can form temporarily in the Columbia sediments.

The hydraulic conductivity of the Columbia aquifer in and around the Station has been determined at different scales by different methods (table 1). The horizontal hydraulic conductivity of the Columbia ranges from 0.4 to $8 \mathrm{ft} / \mathrm{d}$ at the Station as determined from four single-well aquifer (slug) tests (Brockman and others, 1997, p. 14). The median of the four slug tests is $0.7 \mathrm{ft} / \mathrm{d}$. From eight specific capacity tests of wells in the Columbia aquifer on the York-James Peninsula, Laczniak and Meng (1988, p. 57) calculated a median horizontal hydraulic conductivity of $24 \mathrm{ft} / \mathrm{d}$ when adjusted for partial penetration, and a median of $6 \mathrm{ft} / \mathrm{d}$ unadjusted. Harsh and Laczniak (1990, p. F17 and F94) initially estimated an average horizontal hydraulic conductivity of $15 \mathrm{ft} / \mathrm{d}$ for the Columbia aquifer based on lithologic logs and aquifer tests and arrived at a calibrated value of $18 \mathrm{ft} / \mathrm{d}$ in a regional ground-water flow model of the Coastal Plain of Virginia.
The vertical hydraulic conductivity of the Columbia aquifer ranges from 0.00017 to $0.17 \mathrm{ft} / \mathrm{d}$ (table 2) as determined from permeameter tests on five Shelby-tube samples taken from boreholes at the Station (Brockman and others, 1997, p. 17). The median of the five permeameter tests is $0.07 \mathrm{ft} / \mathrm{d}$.

\section{Cornwallis Cave Confining Unit}

The Cornwallis Cave confining unit consists of clay with or without sand lenses or stringers, sandy or silty clay, or clayey silt. This confining unit separates the Columbia aquifer from the Cornwallis Cave aquifer beneath much of the Lackey Plain and impedes vertical flow from the unconfined Columbia aquifer above to the confined Cornwallis Cave aquifer below. The Cornwallis Cave confining unit is dissected by major streams at the Station and is truncated by the Camp Peary scarp. It is absent beneath Croaker Flat (Brockman and others, 1997, p. 17).

Vertical hydraulic conductivity of the Cornwallis Cave confining unit ranges from 0.000031 to $0.014 \mathrm{ft} / \mathrm{d}$ (table 2) based on permeameter tests on five Shelbytube samples taken from bore holes at the Station (Brockman and others, 1997, p. 17). The median of the five permeameter tests is $0.0026 \mathrm{ft} / \mathrm{d}$.

Table 1. Horizontal hydraulic conductivity of the shallow aquifer system in and around the Naval Weapons Station Yorktown, Virginia

[Figures in parentheses are the number of samples; --, no data]

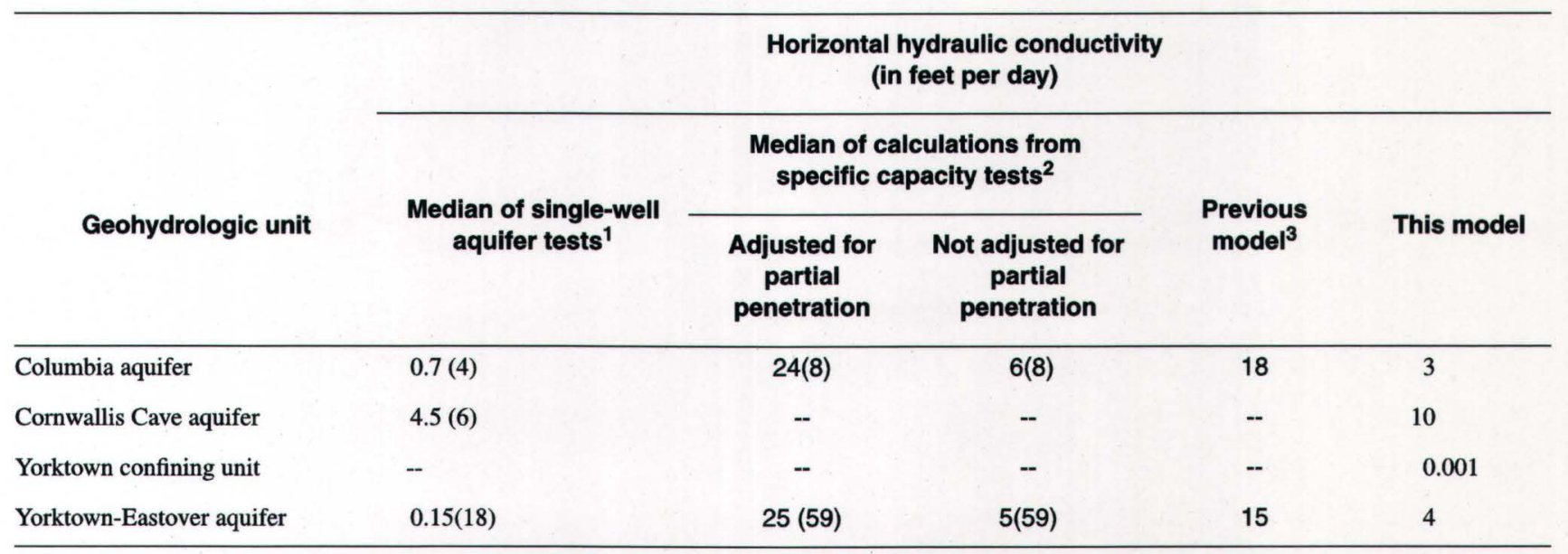

${ }^{1}$ From data files of the U.S. Geological Survey, Richmond, Va.

${ }^{2}$ From Laczniak and Meng, 1988, p. 57.

${ }^{3}$ From Harsh and Laczniak, 1990, p. F 17 and F 94. 
Table 2. Vertical hydraulic conductivity of the shallow aquifer system in and around the Naval Weapons Station Yorktown, Virginia

[Figures in parentheses are the number of samples; --, no data]

\begin{tabular}{lllll}
\hline & & \multicolumn{2}{c}{$\begin{array}{c}\text { Vertical hydraulic conductivity } \\
\text { (in feet per day) }\end{array}$} \\
\cline { 2 - 5 } \multicolumn{1}{c}{ Geohydrologic unit } & Minimum ${ }^{1}$ & Median & Maximum ${ }^{1}$ & This model \\
\hline Columbia aquifer & 0.00017 & $0.07(5)$ & 0.17 & 0.07 \\
Cornwallis Cave confining unit & 0.000031 & $0.0026(5)$ & 0.014 & - \\
Cornwallis Cave aquifer & 0.00062 & $0.042(12)$ & 0.24 & 0.04 \\
Yorktown confining unit & 0.000013 & $0.00012(6)$ & 0.0074 & 0.007 \\
Yorktown-Eastover aquifer & 0.000017 & $0.0068(23)$ & 0.48 & 0.007 \\
Eastover-Calvert confining unit & 0.000006 & $0.0000085(11)$ & 0.00043 & - \\
\hline
\end{tabular}

${ }^{1}$ From Brockman and others, 1997, p.14.

\section{Cornwallis Cave Aquifer}

The Cornwallis Cave aquifer is composed of shell hash with or without some coquina, clay, or silt; clayey or sandy shell hash; very fine grained to medium grained sand; or shelly clay. The aquifer is unconfined at some locations beneath the Lackey Plain and is confined at others (Brockman and others, 1997, p. 21). Karst solution features such as sinkholes in some areas of the Lackey Plain are probably caused by dissolution of calcium carbonate minerals of the Cornwallis Cave aquifer (Brockman and others, 1997, p. 20). The Cornwallis Cave aquifer is dissected by major streams at the Station and is truncated by the Camp Peary scarp. It is absent beneath Croaker Flat (Brockman and others, 1997, p. 17).

The horizontal hydraulic conductivity of the Cornwallis Cave aquifer ranges from 0.3 to $9 \mathrm{ft} / \mathrm{d}$ at the Station as determined from six single-well aquifer (slug) tests (Brockman and others, 1997, p. 24). The median of the six slug tests is $4.5 \mathrm{ft} / \mathrm{d}$ (table 1 ).

Vertical hydraulic conductivity of the Cornwallis Cave aquifer ranges from 0.00062 to $0.24 \mathrm{ft} / \mathrm{d}$ based on permeameter tests of 12 Shelby-tube samples taken from boreholes at the Station (Brockman and others, 1997, p. 27). The median is $0.042 \mathrm{ft} / \mathrm{d}$.

\section{Yorktown Confining Unit}

The Yorktown confining unit is composed of clay, clayey silt, sandy clay, or silty clay with or without some shell hash or sand stringers. This confining unit impedes vertical flow to and from the Yorktown-Eastover aquifer beneath much of the Station; however, the unit is relatively thin beneath much of the Lackey Plain and is absent in some areas (Brockman and others, 1997, p. 26). The Yorktown confining unit has been eroded and dissected by Felgates Creek and some of its tributaries and has been truncated by the York River estuary.

Vertical hydraulic conductivity of the Yorktown confining unit ranges from 0.000013 to $0.0074 \mathrm{ft} / \mathrm{d}$ based on permeameter tests of six Shelby-tube samples taken from bore holes at the Station (Brockman and others, 1997, p. 27). The median of the six permeameter tests is $0.00012 \mathrm{ft} / \mathrm{d}$.

For comparisons to previous studies, the average vertical hydraulic conductivity of the six permeameter tests of the unit was $0.0013 \mathrm{ft} / \mathrm{d}$. Laczniak and Meng (1988, p. 68 and 70) estimated an average vertical hydraulic conductivity of $0.00086 \mathrm{ft} / \mathrm{d}$ for the Yorktown confining unit on the basis of laboratory analyses of core samples from the York-James Peninsula. Harsh and Laczniak (1990, p. F19 and F94) 
initially estimated an average vertical hydraulic conductivity of $0.00346 \mathrm{ft} / \mathrm{d}$ for the Yorktown confining unit on the basis of laboratory analyses of cores and arrived at calibrated a value of $0.000864 \mathrm{ft} / \mathrm{d}$ in a regional ground-water flow model of the Coastal Plain of Virginia.

\section{Yorktown-Eastover Aquifer}

The Yorktown-Eastover aquifer is composed of very fine grained to coarse grained sand, silty sand, silt or sandy clay with or without some conglomerate, shell hash, and clay. The aquifer is confined beneath most of the Station but, is unconfined where it has been partially eroded by Felgates Creek and the York River estuary (Brockman and others, 1997, p. 29).

The horizontal hydraulic conductivity of the Yorktown-Eastover aquifer ranges from 0.004 to $3 \mathrm{ft} / \mathrm{d}$ at the Station as determined from 18 single-well aquifer (slug) tests (Brockman and others, 1997, p. 31). The median is $0.15 \mathrm{ft} / \mathrm{d}$ (table 1). Laczniak and Meng $(1988$, p. 57) calculated a median horizontal hydraulic conductivity of $25 \mathrm{ft} / \mathrm{d}$ when adjusted for partial penetration, and a median of $5 \mathrm{ft} / \mathrm{d}$ unadjusted, from 59 specific capacity tests of wells in the YorktownEastover aquifer on the York-James Peninsula. Harsh and Laczniak (1990, p. F17 and F94) initially estimated an average horizontal hydraulic conductivity of $20 \mathrm{ft} / \mathrm{d}$ for the Yorktown-Eastover aquifer on the basis of lithologic logs and aquifer tests and arrived at a calibrated value of $15 \mathrm{ft} / \mathrm{d}$ in a regional ground-water flow model of the Coastal Plain of Virginia.

Vertical hydraulic conductivity of the YorktownEastover aquifer ranges from 0.000017 to $0.48 \mathrm{ft} / \mathrm{d}$ based on permeameter tests of 23 Shelby-tube samples taken from bore holes (Brockman and others, 1997, p. 27). The median of the 23 permeameter tests is $0.0068 \mathrm{ft} / \mathrm{d}$ (table 2).

Below the Yorktown-Eastover aquifer is the Eastover-Calvert confining unit, a relatively thick unit with a median vertical hydraulic conductivity of $0.0000085 \mathrm{ft} / \mathrm{d}$ (table 2). The top of the EastoverCalvert confining unit marks the bottom boundary of the shallow aquifer system.

\section{GROUND-WATER FLOW SIMULATION}

A deterministic ground-water flow model is a system of governing process equations that numerically simulate measured data and conceptual information about an aquifer system. Data and information about the geometries and hydraulic characteristics of the aquifers, confining units, surface-water bodies, groundwater recharge and discharge rates, and ground-water levels can be incorporated into the system of equations. Data and concepts pertinent to a particular set of objectives can be tested, compared, and refined quantitatively by analyses of numerical ground-waterflow simulations.

A three-dimensional, finite-difference, groundwater flow model was used to represent steady-state ground-water flow of the shallow aquifer system in and around the Naval Weapons Station. The model was calibrated by minimizing the RMSE between measured and simulated water levels. Water levels measured in 47 wells at the Station on or about February 3, 1997, were used for the calibration (Brockman and others, 1997, table 2). The calibrated model was used to determine the ground-water budget and general directions of ground-water flow. The calibrated model and a particle-tracking routine were used to estimate ground-water flow paths, flow rates, and traveltimes from selected sites at the Station.

\section{Ground-Water Flow Assumptions}

Visual MODFLOW version 2.8 @ 1995-1999, the Waterloo Hydrogeologic, Inc. extension of the USGS three-dimensional, finite-difference, groundwater flow model MODFLOW (Harbaugh and McDonald, 1996) was used to simulate and depict ground-water flow for this study. MODFLOW along with MODPATH, a particle-tracking routine (Pollock, 1994), simulate laminar, advective ground-water flow that is assumed to be uniform in temperature and density. Advective ground-water flow, sometimes called plug flow, is the average linear velocity of ground water without dispersion or diffusion. Temperature variations in the shallow ground-water system are small and if considered, would cause insignificant changes to aquifer permeabilities. Similarly, concentrations of chemical constituents in the shallow aquifer system are small when considered at the scale of this study and would not change the density of ground water.

Steady-state (average annual) conditions were assumed. Ground-water levels in the shallow aquifer system fluctuate in response to seasonal 
evapotranspiration rates, but those fluctuations tend to center about an annual average. No significant production wells or recharge wells are open to the shallow aquifer system in the immediate vicinity of the Station (Brockman and others, 1997, p. 37).

Simulations based on these assumptions give an approximation of the potential movement of nonreactive contaminants through a porous medium and are valid for the objectives and the scale of this study. Ground water flows through open channels that may exist in places in the Cornwallis Cave aquifer; such channels are not considered porous media and any flow through them is not represented by this general model of the Station and surrounding area. More rigorous simulations of contaminant movement would require a model constructed with a finer mesh, calibrated to more detailed data, and, depending on the objectives of the study and the specifics of the contaminated sites, may also require consideration of dispersion and (or) density variations caused by changes in chemical concentrations in space and time.

\section{Model Concepts and Design}

The finite-difference method requires that a rectangular grid be defined for the model area and that vertical variations in geohydrologic properties be defined by different layers. Individual geohydrologic units of the Station-area model were assumed to have a uniform hydraulic conductivity, but variable thicknesses, in accordance with previous simulations of ground-water flow for the York-James Peninsula (Laczniak and Meng, 1988) and for the Coastal Plain of Virginia (Harsh and Laczniak, 1990). Some variations in the hydraulic conductivity within the units might be expected from place to place within the model area; however, these variations have not been determined with any degree of certainty at the scale of the individual cells of this model.

The model area encompasses the Station and the full width of the peninsula from the York River to the James River (fig. 1). Ground-water flow was simulated from the peninsular drainage divide that runs across the Lackey Plain near the southern end of the Station north to King Creek and the York River and south to Skiffes Creek and the James River (fig. 4). King Creek, a lowaltitude wetland about $800 \mathrm{ft}$ wide along most of its length and with an estuary at its mouth, forms part of the northern constant-head boundary of layer 1 . Skiffes
Creek, a similar stretch of wetland and estuary south of the Station, forms part of the southern constant-head boundary of layer 1 . The remaining perimeters of the Station-area model are high-altitude surface-water divides and were designated no-flow boundaries.

A variably spaced grid of 65 rows and 61 columns was designed to cover the model area. Cell widths of $400 \mathrm{ft}$, were assigned to the area of primary interest, which includes the low-altitude terrace of Croaker Flat and the northeast half of the Station where topographic relief and stream dissection is significant around Felgates Creek and the Camp Peary scarp. Cells were generally increased in width outward from the finer mesh except where drains and outer boundaries were delineated in more detail. Constant heads were assigned to all of the cells representing impoundments and to wetlands and estuaries at or near sea level (fig. 4).

Drains were designated for all of the streams that are not impounded or tide affected. Drains were used rather than river nodes because flows in the perennial streams incised into the Lackey Plain are generally controlled by ground-water levels; and when groundwater levels fall below the bottoms of the stream beds, the streams soon go dry.

The altitudes of the drains were estimated from 7.5-minute topographic maps. The actual widths of the drains (less than $10 \mathrm{ft}$ ) were generally much smaller than the widths of the nodes representing the groundwater flow system (at least $400 \mathrm{ft}$ ). The conductances of the drains were set at $4,000 \mathrm{ft}^{2} / \mathrm{d}$, the minimal value for a typical drain $400 \mathrm{ft}$ long, $10 \mathrm{ft}$ wide, with a hydraulic conductivity of $1 \mathrm{ft} / \mathrm{d}$ and a bottom thickness of $1 \mathrm{ft}$. Nodes with longer lengths could have been assigned larger conductances, but the model would not have been sensitive to the larger values.

The geohydrologic units of the shallow aquifer system illustrated in figure 3 were represented by three layers in the Station-area model (fig. 5). Layer 1, the topmost layer was assigned the hydraulic properties of the Columbia aquifer beneath Croaker Flat and either the Columbia or the Cornwallis Cave aquifer beneath the Lackey Plain where the Columbia aquifer is discontinuous and the water table cuts through both aquifers (fig. 6).

The Cornwallis Cave confining unit was not simulated directly in the calibrated Station-area model; during the calibration process, however, the vertical hydraulic conductivity of layer 1 was tested using the 


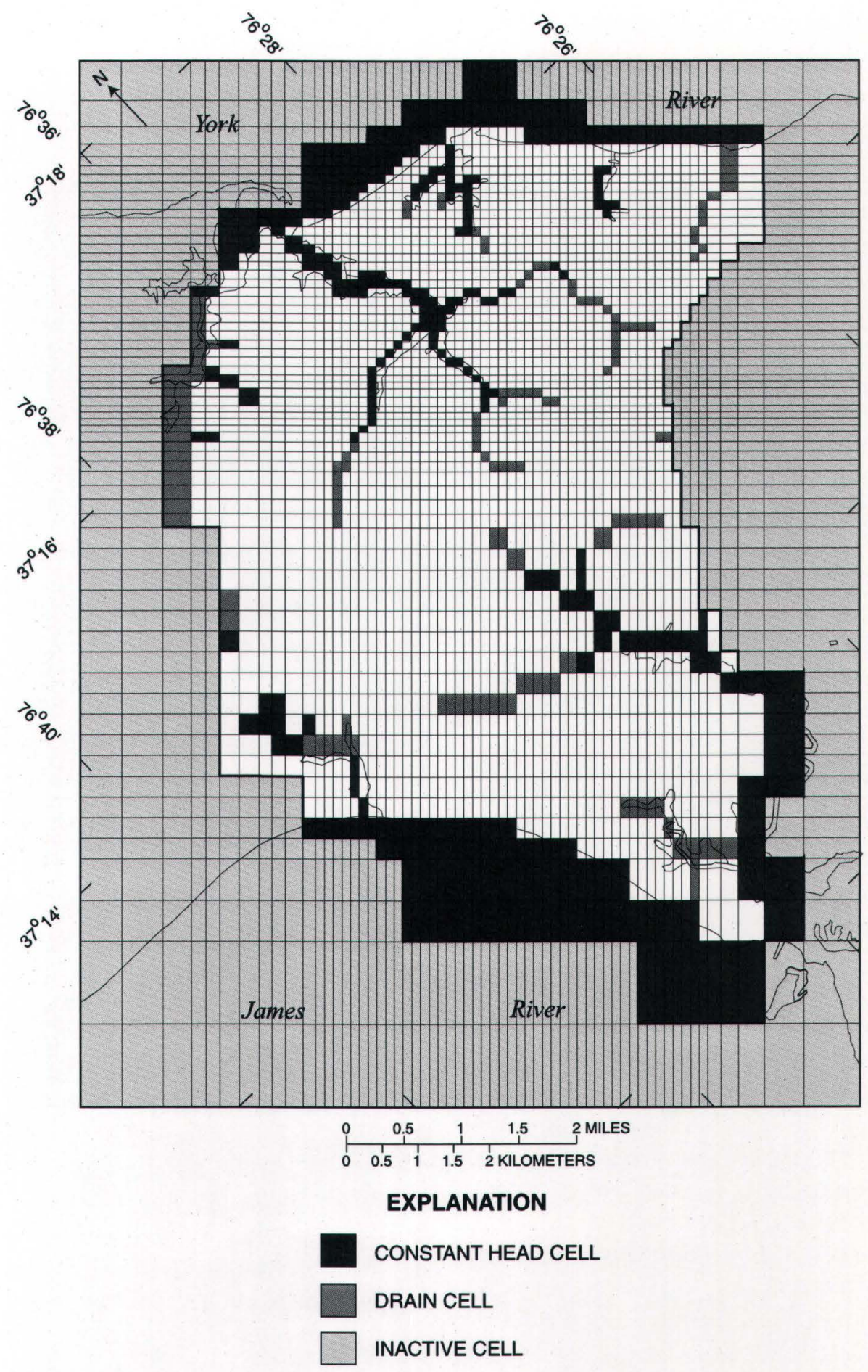

Figure 4. Grid, drain cells, and constant-head cells of the ground-water flow model of the Naval Weapons Station area, Virginia. 


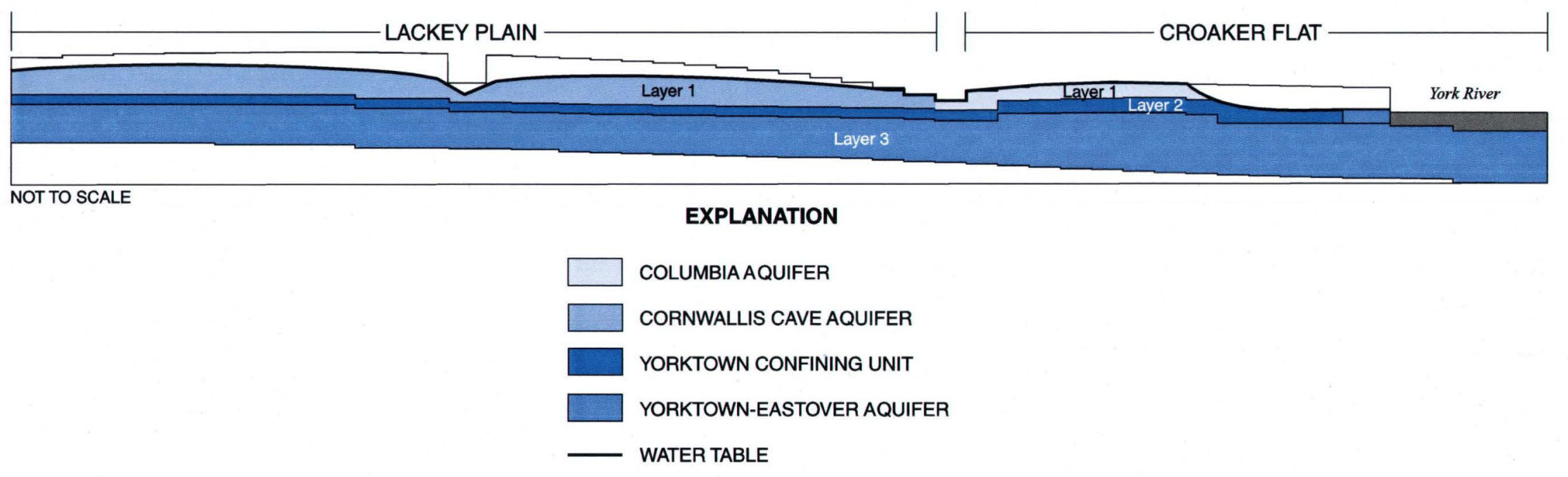

Figure 5. Geohydrologic units and layers of the ground-water flow model of the Naval Weapons Station area, Virginia. 


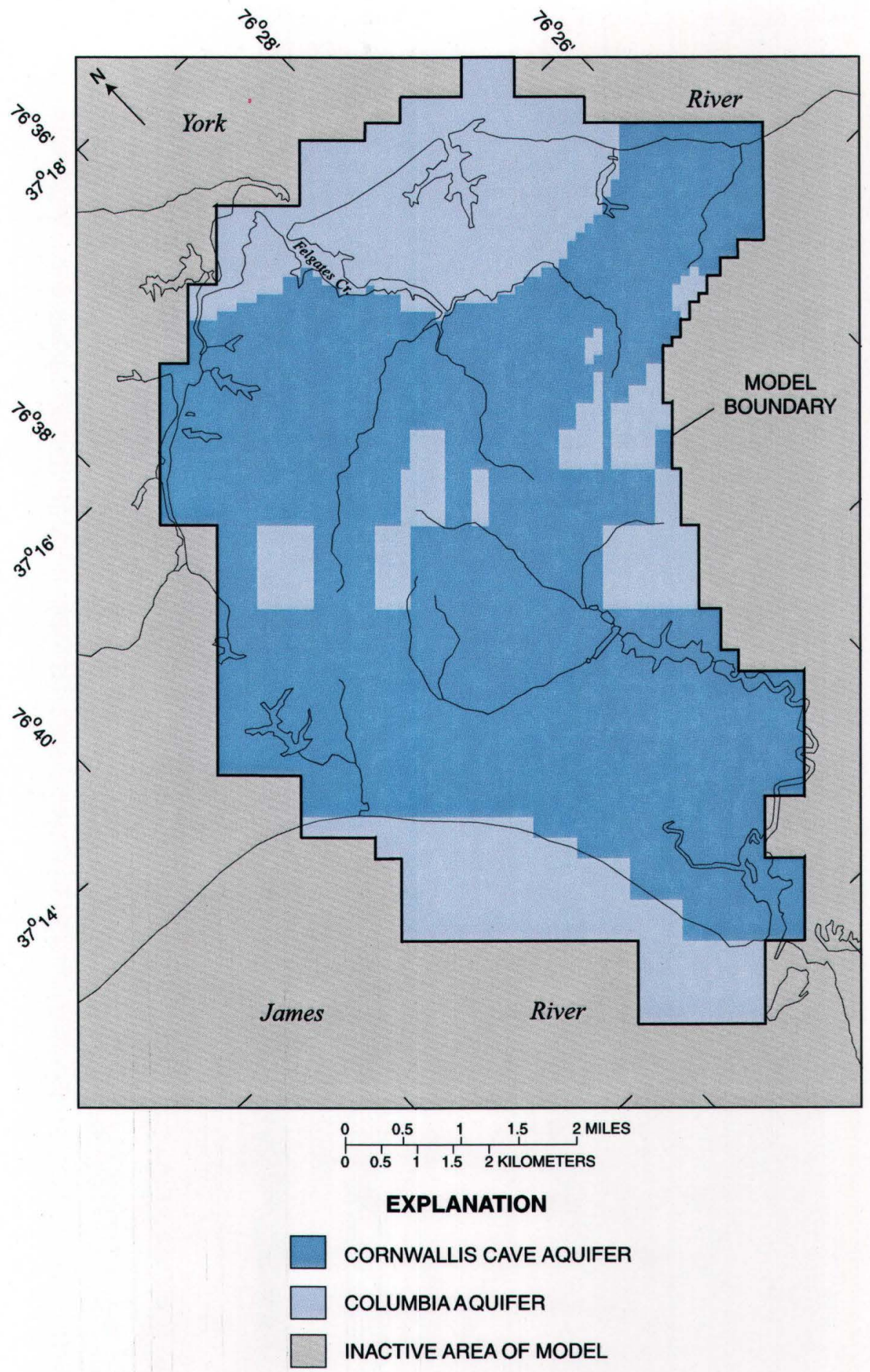

Figure 6. Extent of the Columbia and Cornwallis Cave aquifers in layer 1 of the ground-water flow model of the Naval Weapons Station area, Virginia. 
median value for the Cornwallis Cave confining unit derived from permeameter tests, as well as that of the Columbia aquifer. The Cornwallis Cave aquifer and the Cornwallis Cave confining unit are absent beneath Croaker Flat. Model layer 1 was assigned the properties of the Columbia aquifer at Croaker Flat.

Layer 2 was assigned the hydraulic properties of the Yorktown confining unit, except where it is absent, beneath and between the tributaries to Felgates Creek and beneath the shore of the York River (fig. 7). The hydraulic properties of the Yorktown-Eastover aquifer were assigned to layer 2 in those areas. Layer 3 was assigned the hydraulic properties of the YorktownEastover aquifer throughout the model area.

Layer 1 was simulated as an unconfined aquifer, MODFLOW type 1 (Harbaugh and McDonald, 1996 p. 24). Layer 2 was simulated as a confined/ unconfined aquifer, type 3 , and layer 3 was simulated as a confined aquifer type 0 . The harmonic mean was selected to calculate the inter-block transmissivities of all the layers (Harbaugh and McDonald, 1996 p. 23).

The Strongly Implicit Procedure (SIP) was selected as the numerical solver. The head change criteria was set to $0.001 \mathrm{ft}$ for calibration and sensitivity analysis. Five iteration parameters were selected. The acceleration factor was 1.0 and a userdefined seed of 0.001 was chosen for the solution (Harbaugh and McDonald, 1996, p. 37).

\section{Model Calibration}

Some assumptions guided the calibration process. The horizontal hydraulic conductivity of each unit was assumed to be greater than the vertical hydraulic conductivity because most sediments deposited in water are stratified (Jacob, 1963, p. 274). Confining units deposited in marine environments, such as the Yorktown confining unit, were assumed to have vertical hydraulic conductivities less than or equal to those of confining units deposited in rivers because marine deposits are generally finer grained and more continuous than river sediments. The Cornwallis Cave aquifer was assumed to have a higher hydraulic conductivity than the other units because it is composed of shell hash and, in places, is karstic, forming depressions such as sinkholes.

Initially, a uniform recharge rate of $10 \mathrm{in} / \mathrm{yr}$ $(0.00228 \mathrm{ft} / \mathrm{d})$ was applied to layer 1 , as estimated by assuming surface-water and ground-water divides correspond and using the ground-water discharges calculated by Richardson $(1994$, p. 12). The recharge rate was assumed to be more reliable than the initial values for the hydraulic conductivities of the units. The apparent age of ground water at the Station as determined by analyses of the chlorofluorocarbons suggests that the recharge rates may be slightly less than those estimated by Richardson (D.L. Nelms, USGS, written commun., 1999); therefore, a recharge rate of $9.0 \mathrm{in} / \mathrm{yr}(0.00205 \mathrm{ft} / \mathrm{d})$ was applied and held steady during the last calibration runs.

Initially, the median hydraulic conductivities from the single-well aquifer tests and permeameter tests of samples from the Station were assigned as uniform values for each unit (tables 1 and 2). Simulated water levels from that initial test, however, were unreasonably high, resulting in a RMSE of $80 \mathrm{ft}$. In the next simulation, the horizontal hydraulic conductivity of the Yorktown-Eastover aquifer was increased from $0.15 \mathrm{ft} / \mathrm{d}$ to $1.0 \mathrm{ft} / \mathrm{d}$ which resulted in a significant drop in the simulated heads and a RMSE of $41 \mathrm{ft} / \mathrm{d}$. On the basis of these initial simulations and subsequent simulations testing reasonable ranges in horizontal hydraulic conductivities of other aquifers, it was decided that the results from slug tests probably underestimated the hydraulic conductivities required on the scale of the model units. The model simulations represent unit volumes of individual cells of at least $160,000 \mathrm{ft}^{3}$ while the slug tests displace less than $1 \mathrm{ft}^{3}$ of aquifer in and around the well screens (Brockman and others, 1997, p. 8). Research has indicated that larger values are commonly derived at the scales of multiple-well aquifer tests and ground-water flow models and that smaller values are often derived from slug tests and laboratory analyses such as permeameter tests (Bradbury and Muldoon, 1990, p. 141).

After testing reasonable ranges for the vertical hydraulic conductivity of the aquifers, the median of the permeameter test results were accepted and held steady for the final calibration runs (table 2); because no other data were available for the vertical hydraulic conductivity of the aquifers at the Station.

Horizontal hydraulic conductivities from previous model studies that included the Station were also tested (table 1). Simulating $18 \mathrm{ft} / \mathrm{d}$ for the Columbia aquifer and $15 \mathrm{ft} / \mathrm{d}$ for the YorktownEastover aquifer, as documented by Harsh and Laczniak (1990, F94) resulted in a RMSE of $15 \mathrm{ft}$. 


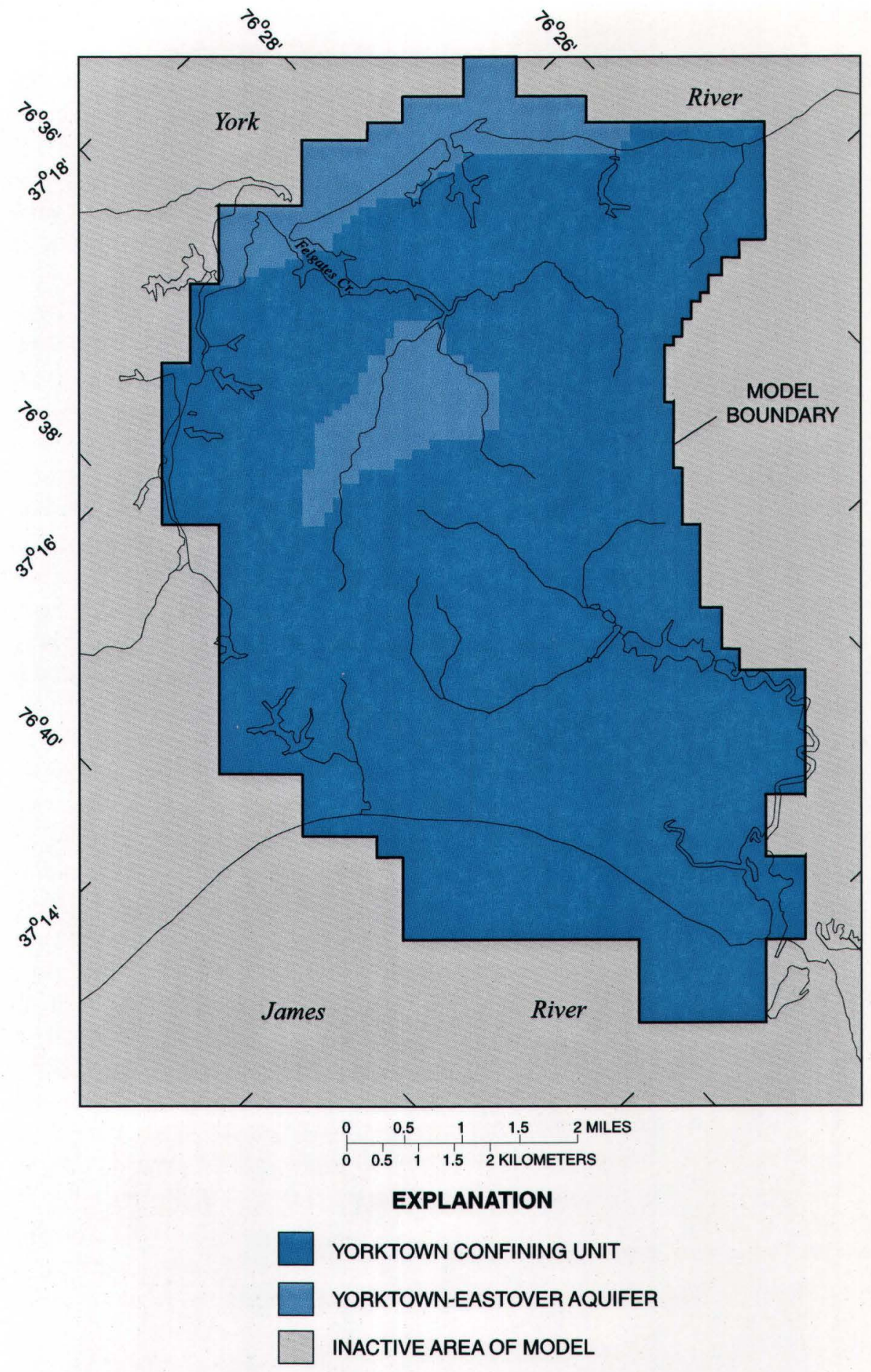

Figure 7. Extent of the Yorktown confining unit and the Yorktown-Eastover aquifer in layer 2 of the ground-water flow model of the Naval Weapons Station area, Virginia. 
The only data available for the horizontal hydraulic conductivities of the Cornwallis Cave aquifer was a median of $4.5 \mathrm{ft} / \mathrm{d}$ from the six slug tests. The lowest RMSE with respect to the hydraulic conductivity of the Cornwallis Cave aquifer and simultaneously for the Columbia aquifer was determined by a series of simulations. A reasonable range of values for the hydraulic conductivity of the Cornwallis Cave aquifer and for the Columbia aquifer were simulated and the RMSE's were recorded and graphed to find the local minimum (best fit) for both within a reasonable range. These tests resulted in a hydraulic conductivity of $7 \mathrm{ft} / \mathrm{d}$ for the Cornwallis Cave aquifer and $3 \mathrm{ft} / \mathrm{d}$ for the Columbia aquifer at a minimum RMSE of $13 \mathrm{ft}$.

Next, the local minimum RMSE for the horizontal hydraulic conductivity of the Cornwallis Cave and simultaneously for the Yorktown-Eastover aquifer were determined by graphing the RMSE's of reasonable ranges of values for both aquifers. This series resulted in a horizontal hydraulic conductivity of $10 \mathrm{ft} / \mathrm{d}$ for the Cornwallis Cave and $4 \mathrm{ft} / \mathrm{d}$ for the Yorktown-Eastover aquifer (table 1) at a minimum RMSE of $11 \mathrm{ft}$.

Finally, reasonable values were simulated and RMSE's were graphed to find the minimum RMSE with respect to the horizontal hydraulic conductivity of the Yorktown-Eastover aquifer and simultaneously with respect to the vertical hydraulic conductivity of the Yorktown confining unit, while adhering to the general calibration rules. This final calibration test resulted in a horizontal hydraulic conductivity of $4 \mathrm{ft} / \mathrm{d}$ for the Yorktown-Eastover aquifer (table 1) and a vertical hydraulic conductivity of $0.007 \mathrm{ft} / \mathrm{d}$ for the Yorktown confining unit (table 2) at a minimum RMSE of 9.7 .

The calibrated model resulted in differences between measured and simulated water levels that were within $\pm 5 \mathrm{ft}$ of the observed water levels for 23 of the 47 wells and were less than $10 \mathrm{ft}$ for the majority of the wells (fig. 8). No pattern is evident in the residuals of measured and simulated water levels and, therefore, the errors are probably random.

Simulated water levels from the calibrated model conform to the general conceptual model of groundwater flow for the Station and the surrounding area. The altitude of the water table simulated as layer 1 was higher than $70 \mathrm{ft}$ above sea level at the ground-water divide of the Lackey Plain near the southern perimeter of the Station, and water levels decreased from there to sea level at the shores of the York River in the northeast and the James River in the southwest where ground water would be expected to discharge (fig. 9).

Simulated water levels also decrease at other places where ground water would be expected to discharge: along King Creek, Skiffs Creeks, and Felgates Creek. Felgates Creek and its tributaries have cut deeply into the Lackey Plain, and the simulated water table decreased precipitously there.

Beneath the interstream areas of the Lackey Plain and Croaker Flat where downward ground-water leakage would generally be expected, simulated water levels for the Yorktown confining unit and the Yorktown-Eastover aquifer (layer 2) were slightly lower than those simulated as the water table (layer 1) (fig. 10). Beneath the rivers and un-impounded streams and, in particular, beneath Felgates Creek and its tributaries where constant-heads cells were specified at or near sea level, simulated water levels for the Yorktown confining unit and the Yorktown-Eastover aquifer were higher than those of the water table, and the model simulated ground-water discharge along those courses, as would be expected.

Simulated water levels for the YorktownEastover aquifer (layer 3) were higher than $60 \mathrm{ft}$ above sea level at the flow divides of the Lackey Plain near the southern perimeter of the Station, and water levels decreased from there to the York River in the northeast and the James River in the southwest where ground water would be expected to discharge (fig. 11). Simulated water levels for the Yorktown-Eastover aquifer were about $20 \mathrm{ft}$ above sea level beneath the confluence of the tributaries to Felgates Creek, where water from the Yorktown aquifer is probably discharging. No evidence other than the general geohydrology and flow simulation, however, indicate such discharges.

\section{Model Sensitivity}

An analysis of model sensitivity is commonly conducted to evaluate the effects of changes in the values of input on the simulation results. In this case, measured ground-water levels were compared to simulated ground-water levels by calculating the RMSE's of the differences. The sensitivity of the calibrated model was also tested to check that a minimum RMSE was achieved with respect to the hydraulic properties. To simplify the sensitivity 


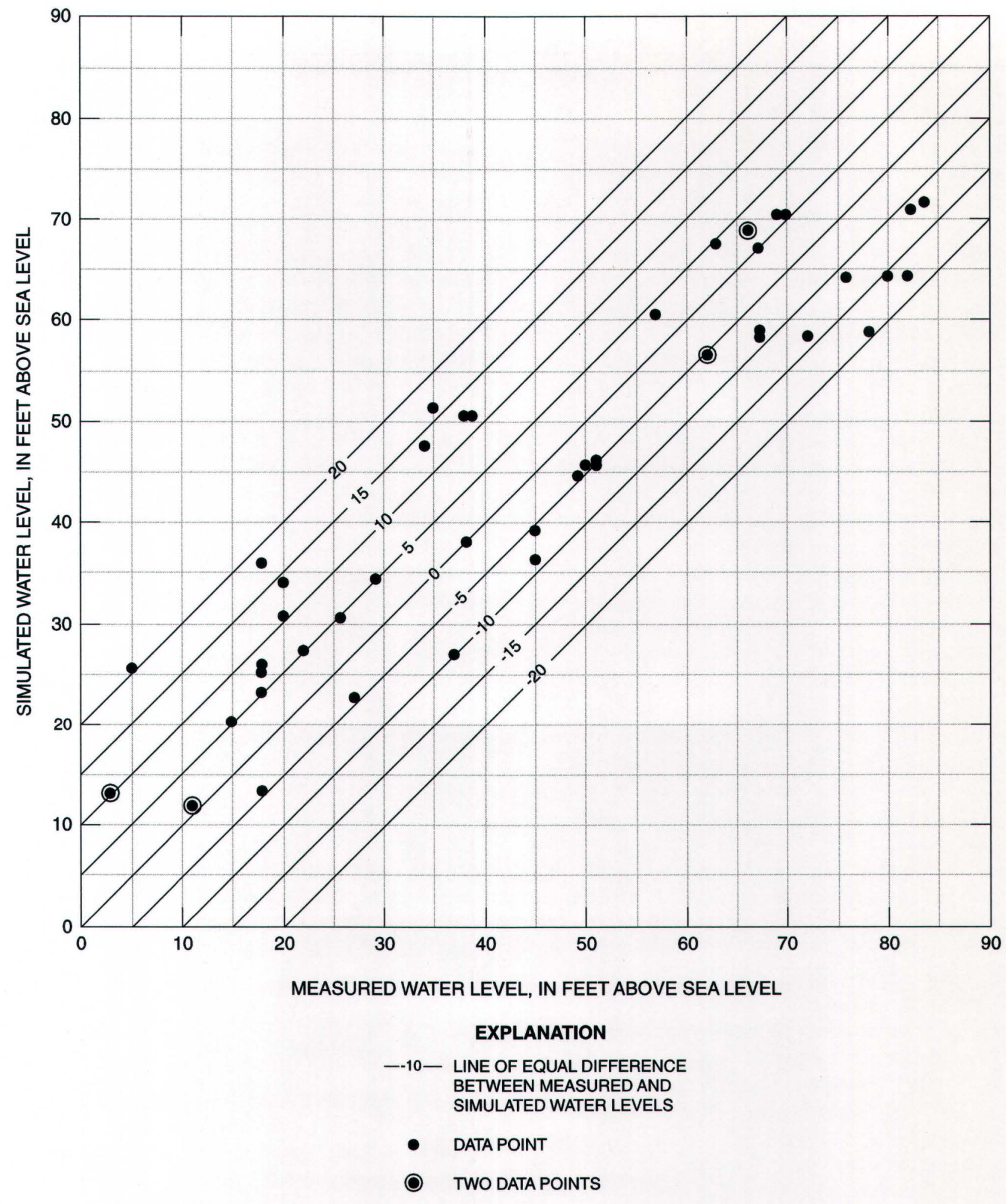

Figure 8. Measured and simulated water levels of the calibrated ground-water flow model of the Naval Weapons Station area, Virginia. 


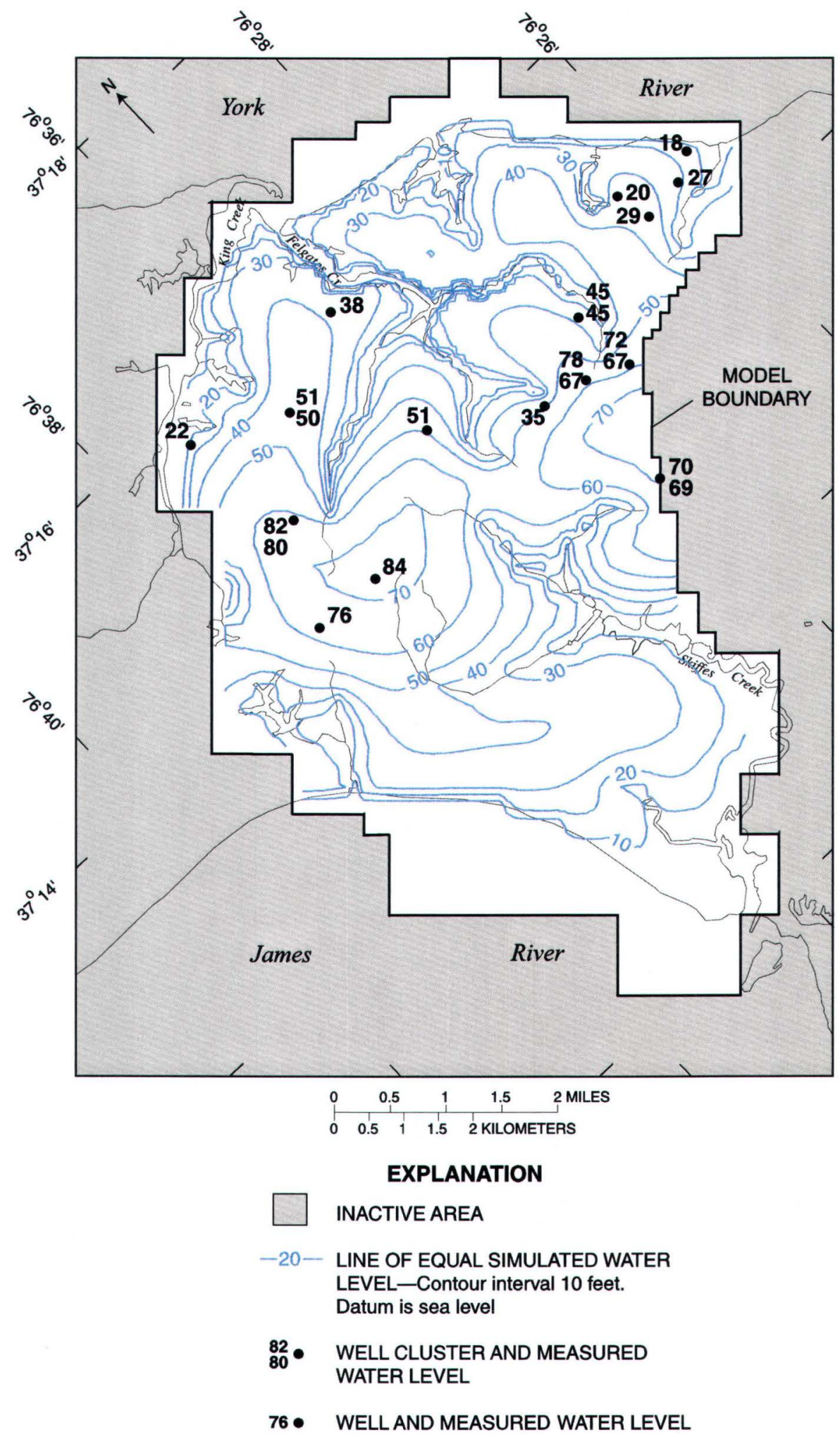

Figure 9. Measured and simulated water levels in layer 1 of the ground-water flow model of the Naval Weapons Station area, Virginia. 


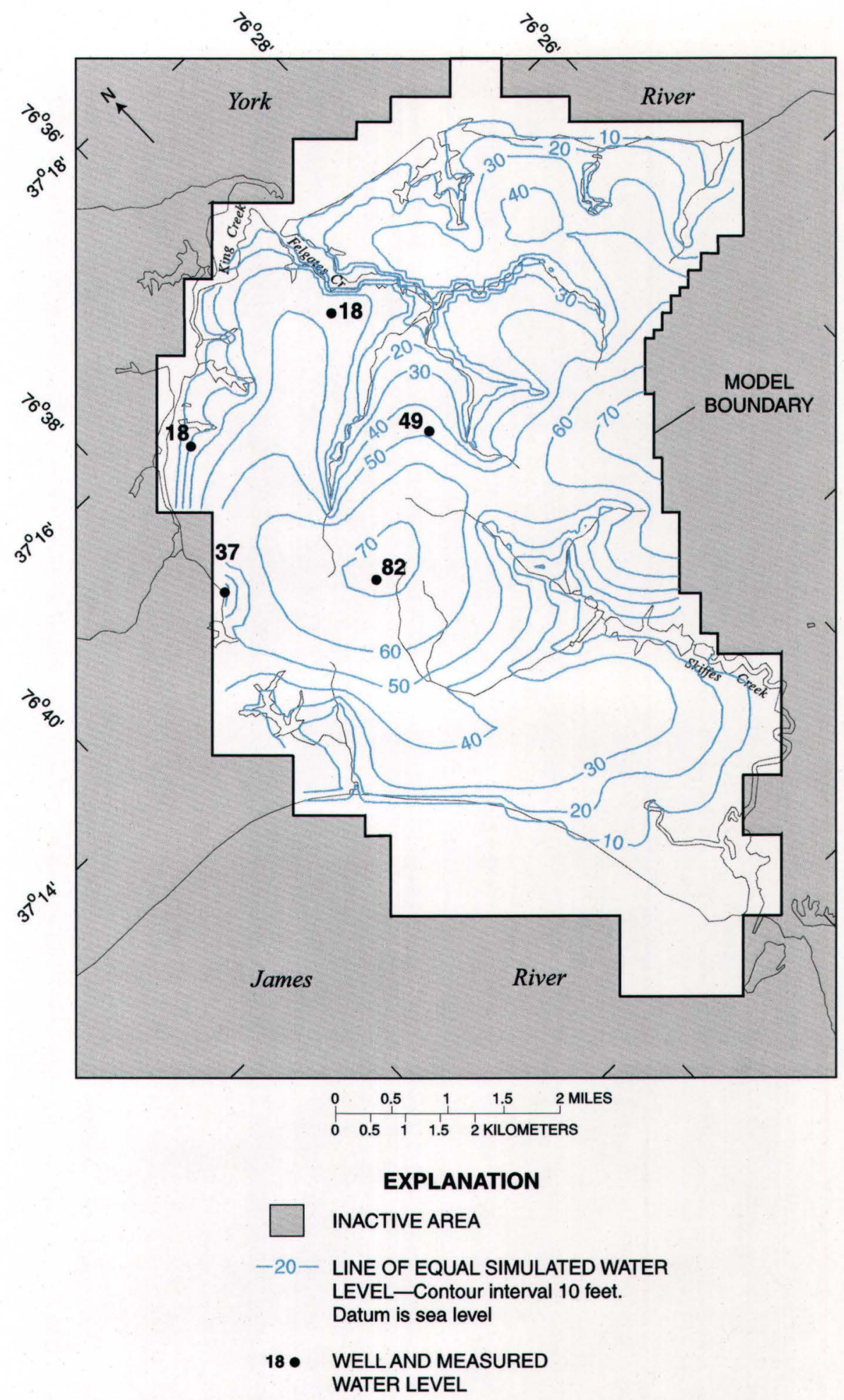

Figure 10. Measured and simulated water levels in layer 2 of the ground-water flow model of the Naval Weapons Station area, Virginia. 


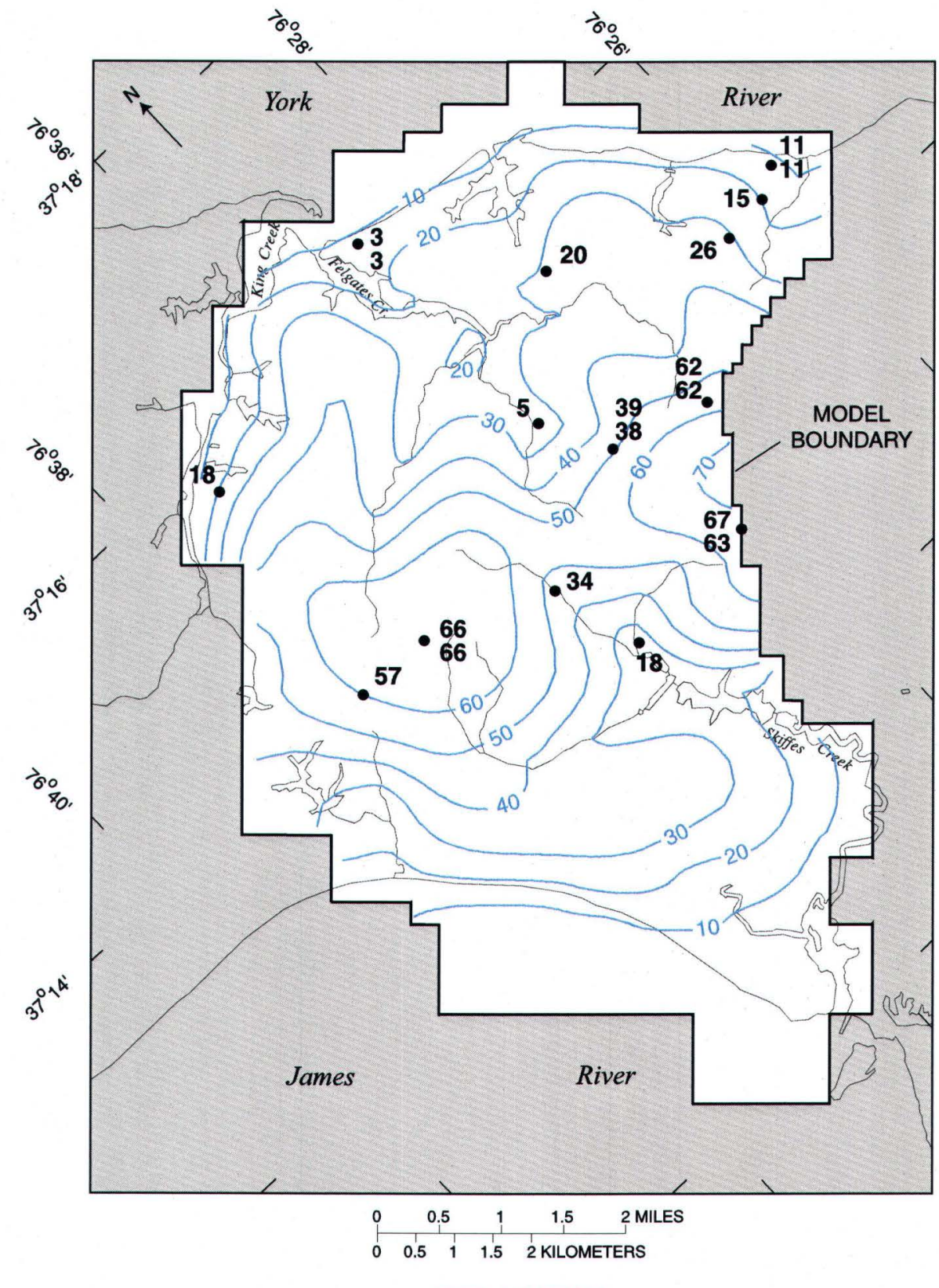

\section{EXPLANATION}

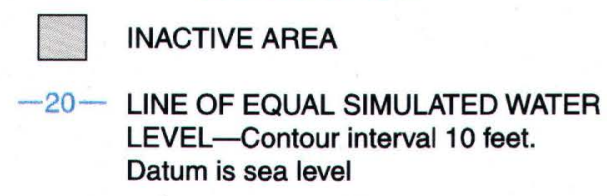

39 - WELL CLUSTER AND MEASURED WATER LEVEL

57 - WELL AND MEASURED WATER LEVEL

Figure 11. Measured and simulated water levels in layer 3 of the ground-water flow model of the Naval Weapons Station area, Virginia. 
analyses, one property was changed at a time while holding the others at the calibrated values. The RMSE's were simulated and plotted on a semilog scale because hydraulic conductivities are nonparametric (fig. 12).

The model was most sensitive to changes in recharge rates, the horizontal hydraulic conductivity of the Cornwallis Cave aquifer, and the horizontal hydraulic conductivity of the Yorktown-Eastover aquifer, respectively. The model was not sensitive to changes in the vertical hydraulic conductivity of the Yorktown confining unit or the horizontal hydraulic conductivity of the Columbia aquifer, which represent the sources of greatest uncertainty in the model.

A minimum RMSE of $9.7 \mathrm{ft}$ was approximated for the calibrated model using reasonable and expected values for hydraulic properties as constrained by the guiding assumptions of the calibration process described above. The calibrated model is a reasonable representation of the shallow aquifer system at steady state. Changing two or more properties of the model, however, such as recharge rates or any combination of horizontal or vertical hydraulic conductivities of the units, could produce similar simulated water levels but different simulated ground-water flow velocities.

\section{GROUND-WATER FLOW ANALYSES}

Simulation results from the calibrated groundwater flow model of the Station area were analyzed to gain insights about the shallow aquifer system. The calibrated model was used to determine the groundwater budget and general directions of ground-water flow. The calibrated model and a particle-tracking routine were used to estimate ground-water flow paths, flow rates, and traveltimes from selected sites at the Station.

\section{Ground-Water Budget}

The ground-water budget for the shallow aquifer system was estimated from the mass balance of the calibrated model. A uniform recharge rate of $9 \mathrm{in} / \mathrm{yr}$ applied to the top layer resulted in a simulated inflow of $1,407,701 \mathrm{ft}^{3} / \mathrm{d}$ to the model area, which accounted for virtually all of the total inflow of $1,427,873 \mathrm{ft}^{3} / \mathrm{d}$ (table 3). Only $20,172 \mathrm{ft}^{3} / \mathrm{d}$, or 1 percent of all simulated inflow, came from constant-head cells, presumably those of the impounded streams.

Fifty-one percent of the simulated outflow from the model $\left(727,308 \mathrm{ft}^{3} / \mathrm{d}\right)$ discharged to drain cells representing streams, and 49 percent $\left(700,566 \mathrm{ft}^{3} / \mathrm{d}\right)$ discharged to constant-head cells, of which a few represented impounded streams, but most represented wetlands and estuaries at or near sea level (table 3).

Analyses of flow between the model layers using ZONEBUDGET (Harbaugh, 1990) indicated that $355,270 \mathrm{ft}^{3} / \mathrm{d}$, or about 25 percent of all the groundwater inflows to the model, leaked downward from

Table 3. Ground-water flow budget of the Naval Weapons Station area model, Virginia

\begin{tabular}{cc}
\hline Component & $\begin{array}{c}\text { Inflow } \\
\text { (cubic feet } \\
\text { per day) }\end{array}$ \\
\hline Recharge & $1,407,701$ \\
Constant heads & 20,172 \\
\hline Total in & $1,427,873$ \\
\hline
\end{tabular}

\begin{tabular}{lc}
\hline Component & $\begin{array}{c}\text { Outflow } \\
\text { (cubic feet } \\
\text { per day) }\end{array}$ \\
\hline Drains & 727,308 \\
Constant heads & 700,566 \\
\hline Total out & $1,427,874$ \\
\hline
\end{tabular}




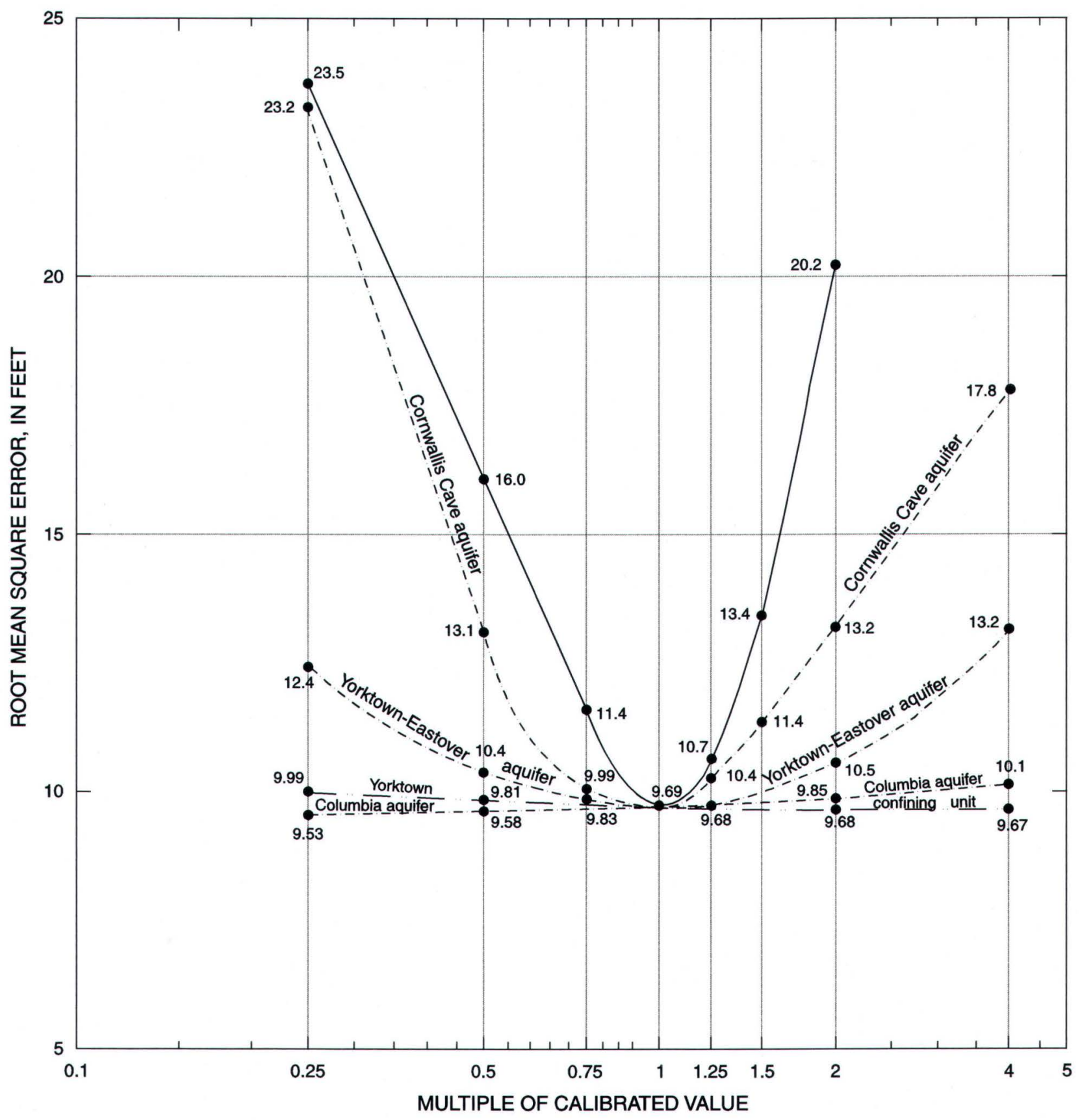

EXPLANATION

9.69 ROOT MEAN SQUARE ERROR BETWEEN MEASURED AND SIMULATED WATER LEVELS

- . - - HORIZONTAL HYDRAULIC CONDUCTIVITY

- - VERTICAL HYDRAULIC CONDUCTIVITY RECHARGE

Figure 12. Sensitivity of the ground-water flow model of the Naval Weapons Station area, Virginia. 
layer 1 to layer 2 . From layer 2 , about $306,080 \mathrm{ft}^{3} / \mathrm{d}$, or 21 percent of all inflows, leaked downward to layer 3 , but elsewhere that same amount leaked upward to layer 2. From layer 2 , about $355,280 \mathrm{ft}^{3} / \mathrm{d}$, or 25 percent of all outflows, leaked upward to the drain or constant-head cells of layer 1 . Of the recharge that was applied to layer 1, the top layer of the Station-area model, 75 percent $\left(1,072,604 \mathrm{ft}^{3} / \mathrm{d}\right)$ discharged directly to the drain and constant-head cells without leaking to deeper layers.

\section{Ground-Water Flow Vectors}

A vector has the properties of direction and magnitude. The vectors calculated from a deterministic ground-water flow model can be used to display the general directions and relative velocities of advective ground-water flow for an aquifer system. Vector plots from the Station-area ground-water flow model as calculated by Visual MODFLOW (c) were used to depict simulated directions and relative velocities of ground-water flow within the perimeter of the Station.

The average linear velocity of ground water is proportional to the hydraulic gradient and the hydraulic conductivity of the units and inversely proportional to the porosity of the units. The porosities of the aquifers and confining units of the shallow aquifer system at the Station have not been determined, but the range in porosities of such sediments are known (Freeze and Cherry, 1979, p. 37). Fine-grained clay and silt deposits tend to have poorly connected, but larger void spaces, than sandy deposits because the mineral plates of the clay can form perpendicular junctures. Therefore, silt and clay deposits generally have lower hydraulic conductivities, but higher porosities, than sand deposits. In the Station-area model, an effective porosity of 30 percent was assumed for layers 1 and 3, which represent primarily sandy aquifers. For layer 2 , which represents primarily the silt and clay of the Yorktown confining unit, an effective porosity of 40 percent was assumed.

In the Coastal Plain of Virginia, ground-water velocities typically are small beneath those relatively flat interstream areas that are unaffected by groundwater withdrawals. Simulated ground-water flow velocities also were small beneath the interstream areas of the Lackey Plain and Croaker Flat, but increased toward the streams and rivers where the hydraulic gradients are generally larger (fig. 13). The maximum simulated velocity of ground-water flow for layer 1 , the topmost layer of the model representing the water table, was $1 \mathrm{ft} / \mathrm{d}$.

The direction of ground-water flow simulated for the water table was radially outward and downward from the interstream areas and upward at the streams and rivers where ground water discharges. If contaminants from the land surface entered the water table at or near the interstream areas of the Station, where hydraulic gradients are smaller, they would tend to migrate more slowly than if they entered closer to the streams or the shores of the rivers, where gradients generally are larger.

The ground-water flow simulations indicate that some ground-water leaks downward from the water table to the Yorktown confining unit and, where the confining unit is absent, to the Yorktown-Eastover aquifer. Simulated velocities of ground-water flow in layer 2 representing the Yorktown confining unit and, where the confining unit is absent, the YorktownEastover aquifer generally were smaller than those of layer 1 (fig. 14). The maximum simulated velocity of layer 2 was $0.3 \mathrm{ft} / \mathrm{d}$ where the confining unit is absent and where water from the Yorktown-Eastover aquifer discharges directly to the streams near the center of the Station. Smaller velocities were simulated for the Yorktown-Eastover aquifer along the shore of the York River where the hydraulic gradients are smaller. Simulated velocities of ground-water flow for the Yorktown confining unit represented throughout the rest of layer 2 were, by comparison, nil. The velocities of any advective-driven contaminants that reached the Yorktown-Eastover aquifer generally would decrease. The velocities of advective-driven contaminants would decrease considerably when entering the Yorktown confining unit because the hydraulic conductivity of the confining unit is small compared to that of the aquifers.

The directions of ground-water flow simulated for layer 3, representing the Yorktown-Eastover aquifer, were similar to those of layer 1, the water table, but the velocities generally were smaller. Smaller velocities were particularly evident beneath the streams and the shorelines of layer 3 where the simulated hydraulic gradients representing the deeper aquifer are substantially smaller than those of the water table (fig. 15). The maximum simulated velocity for layer 3 was $0.2 \mathrm{ft} / \mathrm{d}$. 


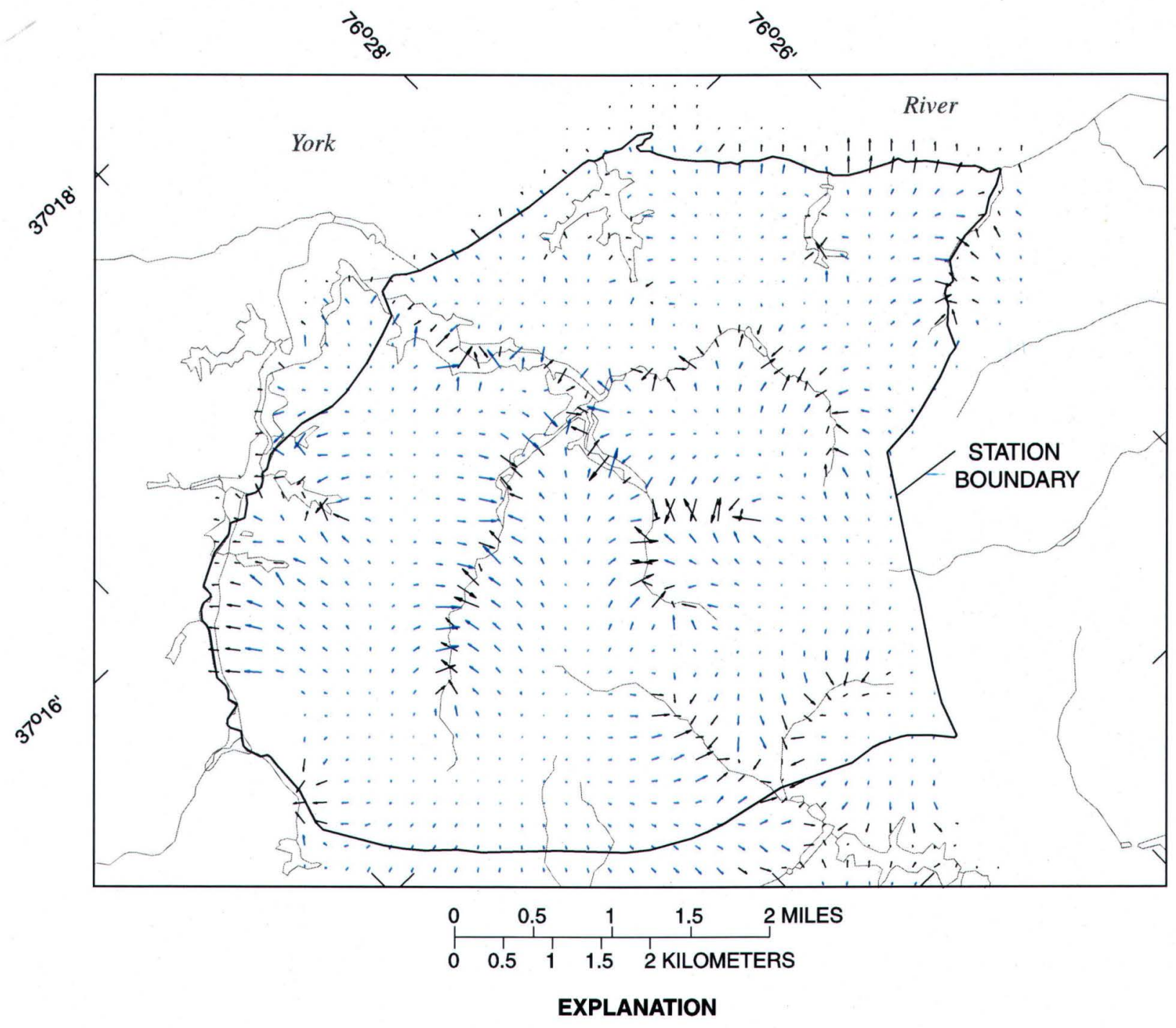

$\rightarrow \quad$ UPWARD GROUND-WATER FLOW VECTOR-

Velocity proportional to length

- DOWNWARD GROUND-WATER FLOW VECTOR-

Velocity proportional to length

Figure 13. Vectors simulated for layer 1 of the ground-water flow model of the Naval Weapons Station area, Virginia. 


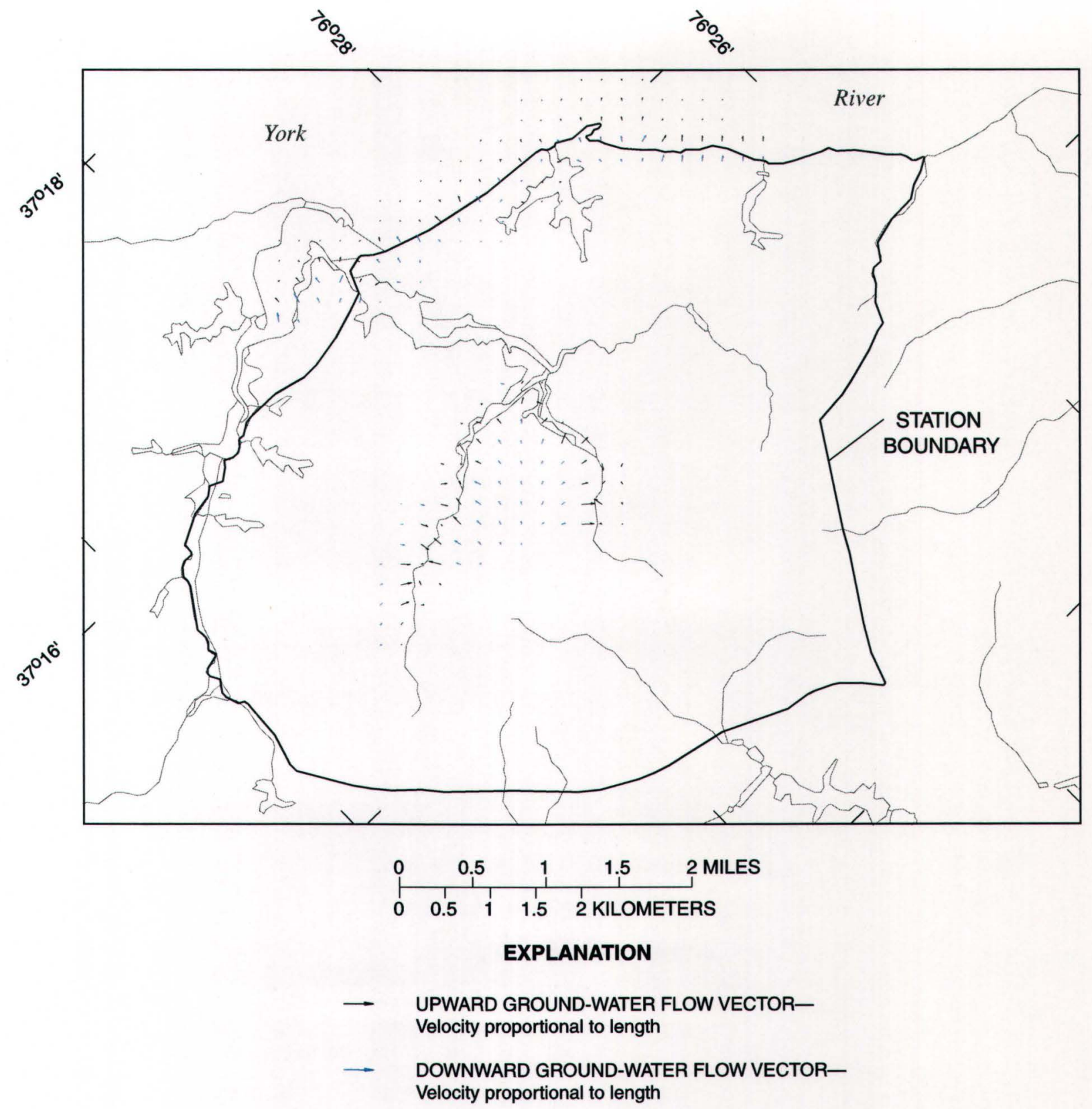

Figure 14. Vectors simulated for layer 2 of the ground-water flow model of the Naval Weapons Station area, Virginia. 


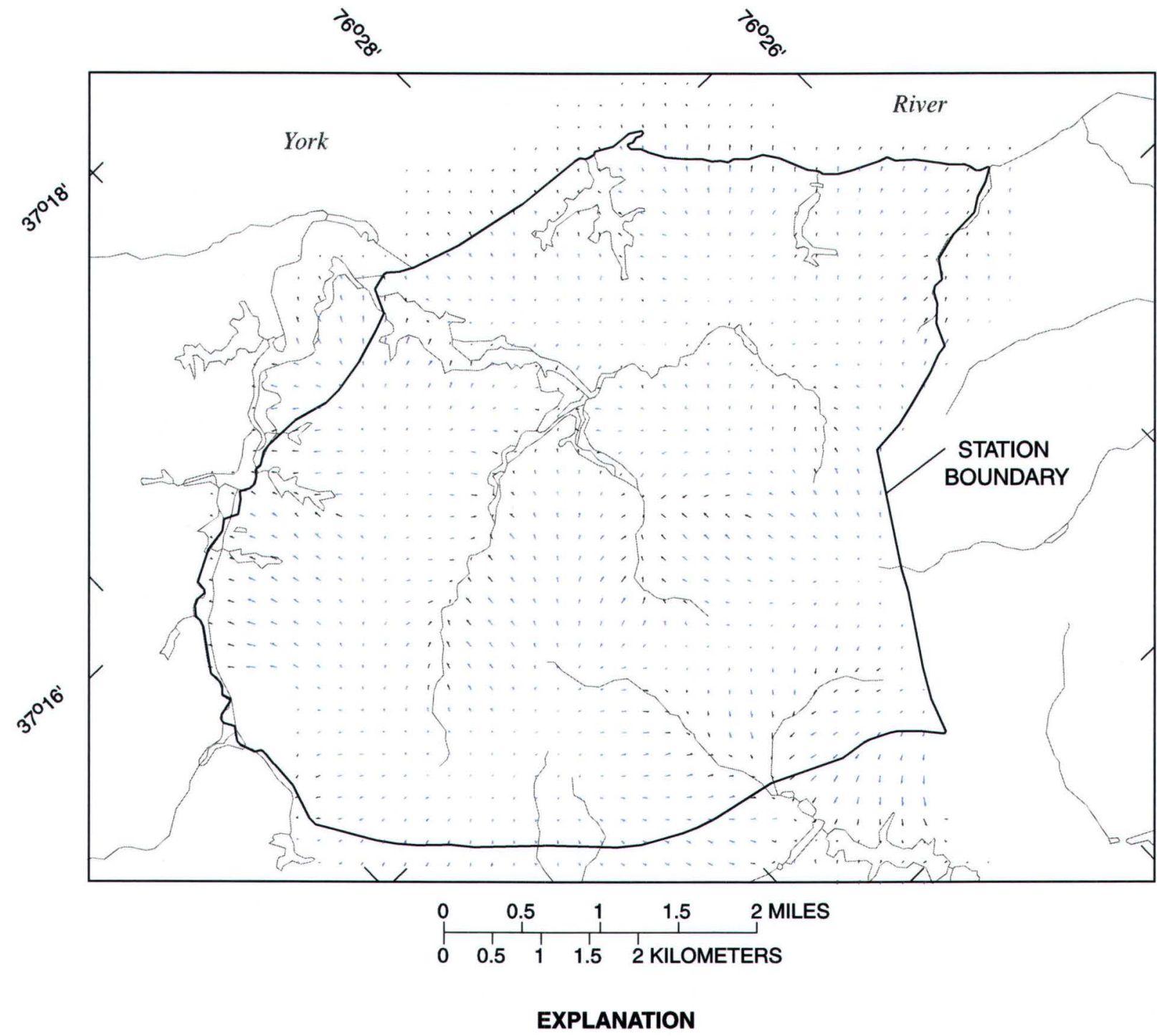

UPWARD GROUND-WATER FLOW VECTOR-

Velocity proportional to length

- DOWNWARD GROUND-WATER FLOW VECTOR-

Velocity proportional to length

Figure 15. Vectors simulated for layer 3 of the ground-water flow model of the Naval Weapons Station area, Virginia. 


\section{Ground-Water Flow Paths}

Ground-water flow paths were simulated from selected sites at the Station to depict typical advective flow for the shallow aquifer system. Along the drainage divide of the Lackey Plain near the southern perimeter of the Station, ground water flows slowly downward and radially outward through the Columbia and Cornwallis Cave aquifers, as indicated by the forward tracking of 10 particles started in the middle of layer 1 below the highest point along the divide (fig. 16). After traveling through the Columbia and Cornwallis Cave aquifers for 50 to 100 years, these particles passed down through the Yorktown confining unit, which is generally leaky and relatively thin across much of the Lackey Plain, then continued laterally through the Yorktown-Eastover aquifer toward the perennial streams where ground water discharges as base flow. The simulation was stopped when the particles entered an internal sink or had traveled for 200 years.

Some general conclusions about possible contaminant migration can be inferred from this simulation. Any contaminants moving with advective ground-water flow near the divide would move relatively slowly at first because of the small hydraulic gradients. The direction of contaminant migration would be determined by which sides of the divide the contaminants entered the shallow aquifer system. Their velocity would increase down some flow paths as the hydraulic gradient increased, but would decrease if a confining clay or silt unit of considerable thickness were encountered.

To investigate the depiction of ground-water flow as represented in the Station-area model by 400 $\mathrm{ft}$-wide cells, flow paths were simulated from two sites about $400 \mathrm{ft}$ apart. At Croaker Flat near the northern perimeter of the Station, 10 particles were tracked forward from the middle of layer 1, five particles from beneath site 11 and five particles from beneath site 17 (fig. 17). The simulation was stopped when the particles entered an internal sink or had traveled for 200 years.

The simulated flow paths indicate that, from the middle of layer 1 beneath those sites, ground water flows downward through the Columbia aquifer and the Yorktown confining unit into the Yorktown-Eastover aquifer. The 10 particles traveled in similar directions and at similar velocities eastward and downward through the Columbia aquifer, through the Yorktown confining unit, and into the Yorktown-Eastover aquifer where they changed directions at about the same time, turning toward the northeast after traveling less than 50 years. The 10 particles continued traveling in similar fashion through the Yorktown-Eastover aquifer, for another 50 years. As the particles approached potential discharge areas, their paths began to diverge; most of the particles discharged to one of the tributaries west of Indian Field Creek (fig. 18). Two particles that were started from beneath site 17 , however, traveled for another 100 years and discharged to the York River.

The simulations indicate the divergent flow paths and traveltimes that are possible throughout the shallow aquifer system of the Station. The simulations of the Station-area model, however, serve only as approximations of the potential movement of ground water and of contaminants moving with advective ground-water flow. The model was not designed to accurately simulate ground-water flow paths through local karst features. In particular, the confining units of the shallow aquifer system were simulated as relatively thin and leaky units in accordance with the general conceptual model. Locally, however, the confining units could vary considerably in thickness. The model also was not designed to accurately simulate flow paths at the scales commonly encountered for site investigations. More accurate simulations of ground-water flow paths at local scales could be accomplished using smaller model cells to depict finer resolutions and greater detail. More detailed data on aquifer and confining unit properties as wells as water levels would also be needed to more accurately define local flow paths. Also, depending on the objectives of the study and the specifics of the investigation, contaminant dispersion, diffusion, and retardation might need to be considered. If the contaminants were lighter or more dense than water, then variable-density flow also might need to be considered. 


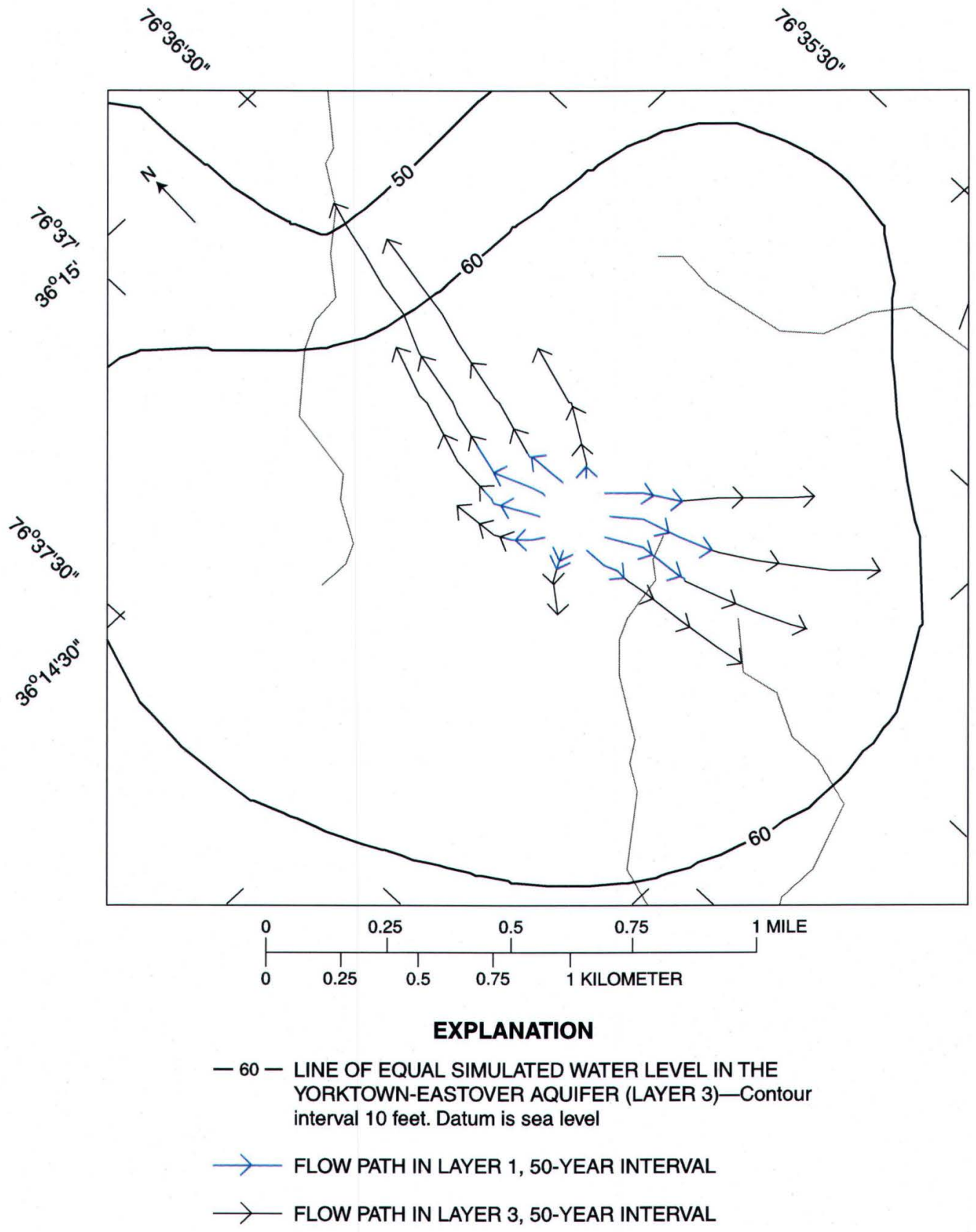

Figure 16. Ground-water flow paths simulated from the drainage divide near the southern perimeter of the Naval Weapons Station Yorktown, Virginia. 


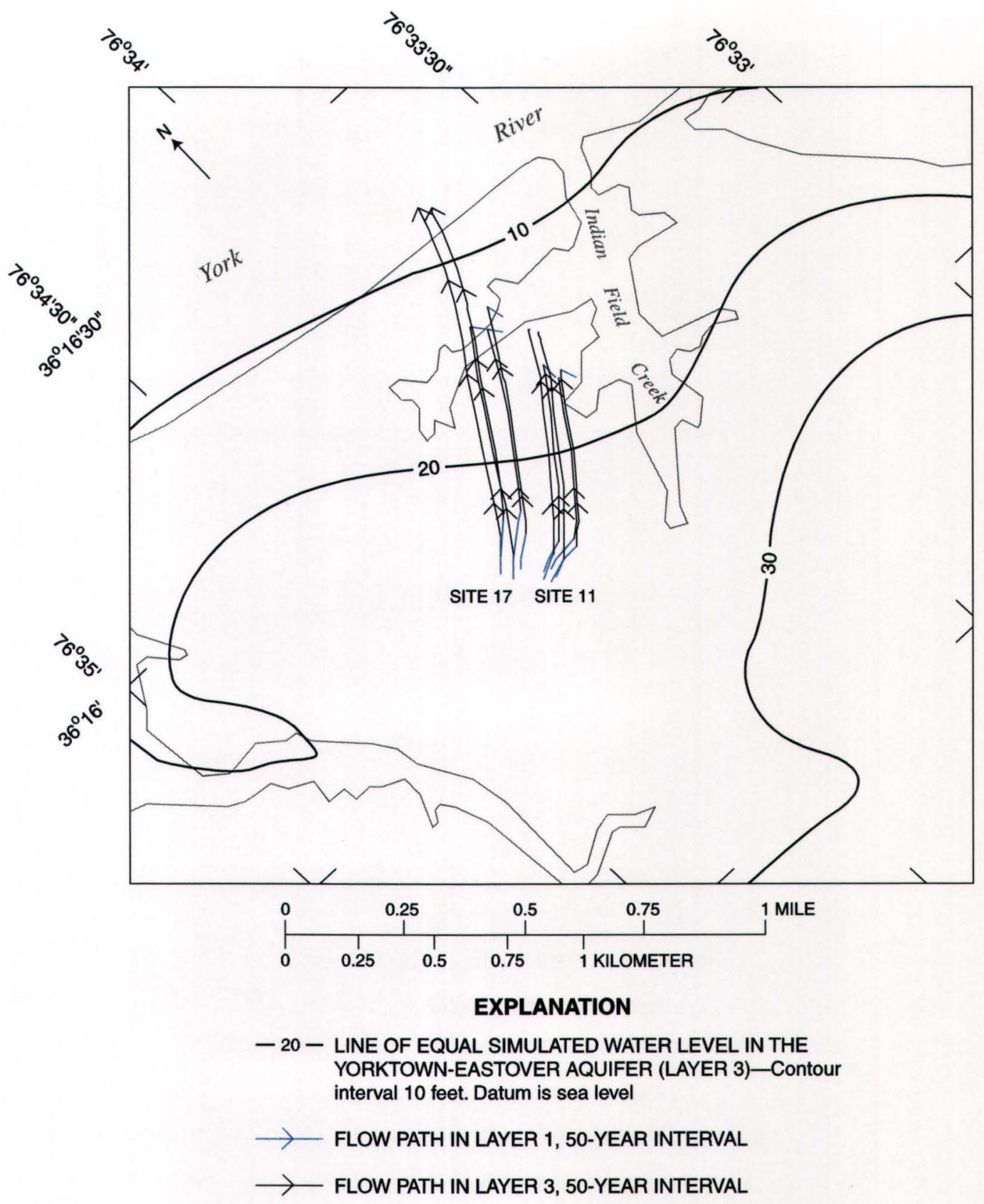

Figure 17. Ground-water flow paths simulated from sites 11 and 17 of the Naval Weapons Station Yorktown, Virginia. 


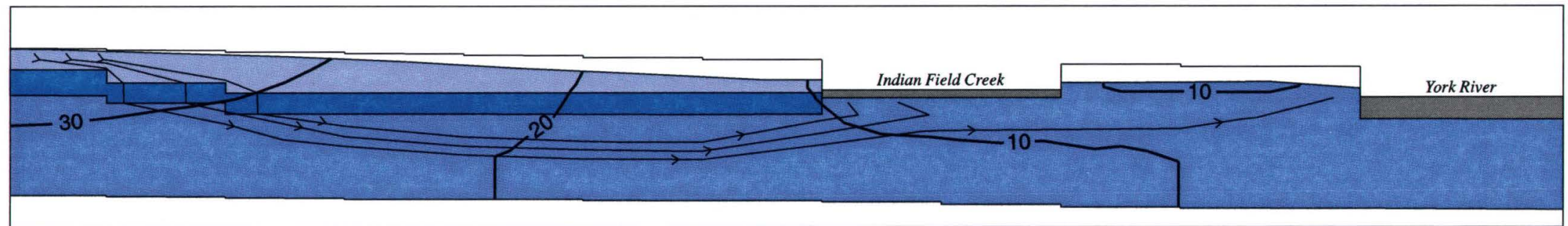

NOT TO SCALE

\section{EXPLANATION}

-10- LINE OF EQUAL SIMULATED WATER LEVELContour interval 10 feet. Datum is sea level

\section{$\square$ COLUMBIA AQUIFER}

YORKTOWN CONFINING UNIT

YORKTOWN-EASTOVER AQUIFER

$\longrightarrow$ FLOW PATH, 50-YEAR INTERVAL

Figure 18. Simulated ground-water flow paths from site 17 of the Naval Weapons Station Yorktown, Virginia. 


\section{SUMMARY}

The Environmental Directorate of the Naval Weapons Station Yorktown, Virginia, is concerned about contamination of ground water at the Station. The Station was placed on the National Priorities (Superfund) List in 1992.

Ground water at the Station flows through a shallow system of layered aquifers and leaky confining units of the Coastal Plain of Virginia. The units of the shallow aquifer system are the Columbia aquifer, the Cornwallis Cave confining unit, the Cornwallis Cave aquifer, the Yorktown confining unit, and the Yorktown-Eastover aquifer. A relatively thick, continuous regional confining unit called the EastoverCalvert confining unit separates the shallow aquifer system from deeper confined aquifers beneath the Station.

Recharge to the shallow aquifer system originates as precipitation that falls directly on the Station and percolates through the unsaturated zone to the water table. Ground water flows from interstream areas beneath higher altitudes to streams, springs, and estuaries at lower altitudes where the ground water is discharged. The Camp Peary scarp runs across the Station separating a high terrace called the Lackey Plain from a low terrace along the York River called Croaker Flat.

A three-dimensional, finite-difference, groundwater flow model was used to simulate steady-state ground-water flow of the shallow aquifer system in and around the Station. Ground-water flow was simulated from the peninsular drainage divide that runs across the Lackey Plain near the southern end of the Station north to King Creek and the York River and south to Skiffes Creek and the James River. Layer 1, the topmost layer, was assigned the hydraulic properties of the Columbia aquifer beneath Croaker Flat and either the Columbia or the Cornwallis Cave aquifer beneath the Lackey Plain where the Columbia aquifer is discontinuous and the water table cuts through both aquifers. Layer 2 was assigned the hydraulic properties of the Yorktown confining unit or the Yorktown-Eastover aquifer. Layer 3 was assigned the hydraulic properties of the Yorktown-Eastover aquifer throughout the model area.

The model was calibrated by minimizing the root mean square error between measured and simulated water levels. Water levels measured in 47 wells at the Station on or about February 3, 1997, were used for the calibration. The calibrated model was then used to calculate the ground-water budget and to determine the general directions of ground-water flow. The calibrated model and a particle-tracking routine were used to estimate ground-water flow paths and traveltimes from selected sites at the Station.

A uniform recharge rate of $9 \mathrm{in} / \mathrm{yr}$ applied to layer 1 , the top layer of the calibrated model, resulted in a simulated inflow of $1,407,701 \mathrm{ft}^{3} / \mathrm{d}$ to the model area and accounted for virtually all of the total inflow of $1,427,873 \mathrm{ft}^{3} / \mathrm{d}$. Fifty-one percent of the simulated outflow from the model $\left(727,308 \mathrm{ft}^{3} / \mathrm{d}\right)$ discharged to drain cells representing streams, and 49 percent $\left(700,566 \mathrm{ft}^{3} / \mathrm{d}\right)$ discharged to the constant-head cells, a few of which represented impounded streams, but most of which represented wetlands and estuaries at or near sea level. Of the recharge that was applied to layer 1, 75 percent discharged directly to the drain and constant-heads cells without leaking to deeper layers, while 25 percent leaked to layer 2 , and 21 percent leaked to layer 3 before returning as upward flow to discharge to the drain and constant-head cells of layer 1.

Simulated ground-water flow velocities of the Station-area model were small beneath the interstream areas of the Lackey Plain and Croaker Flat, but increased toward the streams and rivers where the hydraulic gradients are larger. If contaminants from the land surface entered the water table at or near the interstream areas of the Station, where hydraulic gradients are smaller, they would tend to migrate more slowly than if they entered closer to the streams or the shores of the rivers where gradients generally are larger. The maximum simulated flow velocity was $1 \mathrm{ft} / \mathrm{d}$ in layer $1,0.3 \mathrm{ft} / \mathrm{d}$ in layer 2 , and $0.2 \mathrm{ft} / \mathrm{d}$ in layer 3 .

The ground-water flow simulations indicate that some ground water leaks downward from the water table to the Yorktown confining unit and, where the confining unit is absent, to the Yorktown-Eastover aquifer. The velocities of advective-driven contaminants would decrease considerably when entering the Yorktown confining unit because the hydraulic conductivity of the confining unit is small compared to that of the aquifers.

Any contaminants that moved with advective ground-water flow near the ground-water divide of the Lackey Plain would move relatively slowly because the hydraulic gradients are small there. The direction in which the contaminants would move, however, would be determined by precisely where the contaminants entered the water table. 
Flow paths from two sites about $400 \mathrm{ft}$ apart beneath Croaker Flat near the northern perimeter of the Station were simulated to investigate the depiction of ground-water flow represented by cell widths of $400 \mathrm{ft}$. The simulations indicate that beneath Croaker Flat, ground water flows downward through the Columbia aquifer and the Yorktown confining unit into the Yorktown-Eastover aquifer. The flow paths from the two sites were uniform and similar at first but diverged and discharged to different tributaries of Indian Creek or to the York River. The simulations indicate the complexity and the possibly divergent paths and traveltimes that are possible at the Station.

The simulations are approximations of the movement of ground water and contaminants moving with advective ground-water flow. General concepts about possible contaminant migration at the Station can be inferred from these simulations. The Station-area model is not detailed enough, however, to accurately simulate ground-water flow at the scales commonly encountered in site remediation. More accurate simulations of ground-water flow paths at local scales could be accomplished using smaller model cells to depict finer resolutions and greater detail. More detailed data on aquifer properties, confining units, and water levels would also be needed to more accurately define local flow paths.

\section{REFERENCES CITED}

Bradbury, K.R. and Muldoon, M.A., 1990, Hydraulic conductivity determinations in unlithofied glacial and fluvial materials, in Ground-Water and Vadose-Zone Monitoring, ASTM STP 1053, D.M. Nielson and A.I. Johnson, Eds.: American Society of Testing Materials reprint, Philadelphia, $\mathrm{Pa}$., pp. 138-151.

Brockman, A.R., Nelms, D.L., Harlow, G.E., Jr., and Gildea, J.J., 1997, Geohydrology of the shallow aquifer system, Naval Weapons Station Yorktown, Yorktown, Virginia: U.S. Geological Survey Water-Resources Investigations Report 97-4188, $81 \mathrm{p}$, and $1 \mathrm{pl}$.

C.C. Johnson and Associates, Inc. \& CH2MHill, 1984, Initial Assessment study of Naval Weapons Station, Yorktown, Virginia, July 1984.

Federation of American Scientists, 1997, Nuclear Forces Guide: Federation of American Scientists, accessed February 1, 1999, at URL http://www.fas.org/nuke/guide/usa/facility/ yorktown.htm, 3 p.

Freeze, R.A. and Cherry, J.A., 1979, Groundwater: Prentice Hall, Englewood, New Jersey, 604 p.
Harbaugh, A.W. and McDonald, M.G., 1996, User's documentation for MODFLOW-96, an update to the U.S. Geological Survey modular finite-difference, groundwater flow model: U.S. Geological Survey Open-File Report 96-485, in The Official U.S.G.S. MODFLOW used in Visual MODFLOW, Waterloo Hydrogeologic, Inc., Waterloo, Ontario, Canada, 63 p.

Harbaugh, A.W., 1990, A computer program for calculating subregional water budgets using results from the U.S. Geological Survey modular three-dimensional finitedifference ground-water flow model: U.S. Geological Survey Open-File Report 90-392, 46 p.

Harsh, J.F. and Laczniak, R.J., 1990, Conceptualization and analysis of ground-water flow system in the Coastal Plain of Virginia and adjacent parts of Maryland and North Carolina: U.S. Geological Survey Professional Paper 1404-F, 100 p.

Johnson, G. H., 1972, Geology of the Yorktown, Poquoson West, and Poquoson East quadrangles, Virginia: Virginia Division of Mineral Resources Reports of Investigations 30,57 p., 3 pl.

Jacob, C.E., 1963, Correction of drawdowns caused by a pumped well tapping less than full saturated thickness, in Bental, Ray, compiler, Methods of determining permeability, transmissivity, and drawdown: U.S. Geological Survey Water-Supply Paper 1536-I, p. 272282.

Laczniak, R.J. and Meng, A.A., III, 1988, Ground-water resources of the York-James Peninsula of Virginia: U.S. Geological Survey Water-Resources Investigations Report 88- 4059, 178 p.

Meng, A.A., III and Harsh, J.F., 1988, Hydrogeologic framework of the Virginia Coastal Plain: Regional Aquifer-System Analysis: U.S. Geological Survey Professional Paper 1404-C, 81 p., 4 pl.

Naval Weapons Station, 1993, Proud of our past: focused on our future: Yorktown, Virginia, Naval Weapons Station, 75th Anniversary Publication.

Pollock, D.W., 1994, User's guide for MODPATH/MODPLOTPLOT, version 3: A particle tracking post-processing package for MODFLOW, the U.S. Geological Survey finite-difference ground-water flow model: U.S. Geological Survey Open-File Report 94-464, 236 p.

Richardson, D.L., 1994, Ground-water discharge from the Coastal Plain of Virginia: U.S. Geological Survey WaterResources Investigations Report 93-4191, 15 p., 1 pl.

U.S. Department of the Navy, 1995, DON Environmental Restoration Plan for fiscal years 1996-2000: Yorktown Naval Weapons Station, Yorktown, Virginia.

U.S. Environmental Protection Agency Region III, Commonwealth of Virginia, and the U.S. Department of the Navy, 1994, U.S. Department of the Navy, Naval Weapons Station-Yorktown, Yorktown, Virginia, Federal Facilities Agreement under CERCLA Section 120: Administrative Docket Number: III-FCA-CERC-009, 72 p. 